\begin{tabular}{|l|c|c|c|r|}
\hline $\begin{array}{l}\text { Cuadernos de Investigación Geográfica } \\
\text { Geographical Research Letters }\end{array}$ & 2018 & N $^{\circ} 44(1)$ & pp. 15-45 & $\begin{array}{r}\text { ISSN 0211-6820 } \\
\text { eISSN 1697-9540 }\end{array}$ \\
\hline
\end{tabular}

DOI: http://doi.org/10.18172/cig.3362

\title{
LITTLE ICE AGE GLACIERS AND CLIMATE IN THE MEDITERRANEAN MOUNTAINS: A NEW ANALYSIS
}

\section{P.D. HUGHES*}

Department of Geography, School of Environment, Education and Development, The University of Manchester, Manchester M13 9PL, United Kingdom.

\begin{abstract}
Glaciers were common across the Mediterranean mountains during the Little Ice Age. In parts of Turkey some glaciers were several kilometres longer than they are today, whilst in the Pyrenees glaciers were up to several hundred metres longer. In the wettest Mediterranean mountains, such as the Dinaric Alps, many small glaciers and perennial snow patches would have been present. Even in riest and most southerly mountains, such as the High Atlas, small glaciers and perennial snowfields were present. This paper examines the evidence from these two contrasting regions (the western and southern Balkans and the High Atlas) and the climatic significance of glaciers in these areas during the Little Ice Age. Particular focus is given on the climatological controls on glacier mass balance in different climatic conditions. Glaciers in cold and dry climates exhibit different sensitivity to regional climate change compared with glaciers in cold and wet climates. In addition, the factors controlling ablation of glaciers in different climatic regimes can differ considerably, especially the relative contributions and effects of melting and sublimation. All Mediterranean mountain glaciers were strongly controlled by local topoclimatic factors. Avalanche-fed glaciers have proven to be the most resilient to climate change and dramatically increased accumulation from avalanching snow explains the surviving glaciers in the Dinaric Alps and the semi-perennial snow fields of the High Atlas. In addition, geology as well as landscape morphology inherited from Pleistocene glaciations plays a role in explaining the patterns of Little Ice Age glacier distribution and especially the patterns of retreat and survival of these glaciers. The resilience of some of the last remaining Mediterranean glaciers, in the face of warming climate, presents a contradiction and comparisons between glaciers gone and those that remain provides important insight into the future of similar glaciers globally.
\end{abstract}



un nuevo análisis

RESUMEN. Los glaciares fueron comunes en las montañas mediterráneas durante la Pequeña Edad del Hielo. En partes de Turquía, algunos glaciares fueron varios kilómetros más largos de lo que son ahora, mientras en los Pirineos fueron varios cientos de metros más largos. En las montañas mediterráneas más húmedas, como los Alpes Dináricos, se desarrollaron muchos pequeños glaciares y neveros. Incluso en las montañas meridionales más secas, como el Alto Atlas, pequeños glaciares y campos de nieve permanentes estuvieron presentes. Este trabajo examina la evidencia a partir de dos regiones contrastadas (los Balcanes occidentales y meridionales y el Alto Atlas) y la significación climática de los glaciares en estas regiones durante la Pequeña Edad del Hielo. Se pone especial énfasis en los controles climatológicos del balance de masa glaciar bajo distintas condiciones climáticas. Los glaciares en climas fríos y secos muestran diferente sensibilidad al cambio climático regional en comparación con los glaciares en climas fríos y húmedos. Además, los factores que controlan la ablación de los glaciares en diferentes regímenes climáticos pueden variar considerablemente, especialmente por lo que respecta a las contribuciones relativas de la fusión y la sublimación. Todos los glaciares de las montañas mediterráneas estuvieron fuertemente controlados por factores topoclimáticos locales. Los glaciares alimentados por avalanchas han sido los más resilientes al cambio climático, de manera que el incremento que representa la acumulación de nieve por avalanchas explica la supervivencia de glaciares en los Alpes Dináricos y los semi-permanentes campos de nieve del Alto Atlas. Además, la geología y la morfología heredada desde las glaciaciones del Pleistoceno desempeñan un papel importante para explicar los patrones de distribución de los glaciares de la Pequeña Edad del Hielo y en especial los patrones de retroceso y supervivencia de esos glaciares. La resiliencia de algunos de los últimos glaciares mediterráneos, de cara al cambio climático, presenta contradicciones, y la comparación entre los glaciares que han desaparecido y los que permanecen arroja luz sobre el futuro de glaciares similares.

Key words: very small glaciers, glacierets, niche glaciers, cirque glaciers, glacier sensitivity, melting snow, sublimation, climate change, Dinaric Alps, Pindus Mountains, High Atlas.

Palabras clave: micro-glaciares, heleros, glaciares de nicho, glaciares de circo, sensibilidad glaciar, nieve fundente, sublimación, cambio climático, Alpes Dináricos, Montañas de Pindo, Alto Atlas.

* Corresponding author: P.D. Hughes, Department of Geography, School of Environment, Education and Development, The University of Manchester, Manchester M13 9PL, United Kingdom.E-mail address: philip.hughes@manchester.ac.uk 


\section{Introduction}

The Mediterranean mountains have been repeatedly glaciated through the Quaternary (Hughes and Woodward, 2006, 2017). Of course, the largest glaciations occurred during the Pleistocene cold stages. However, glaciers are still present today and were much more widespread 150 years ago at the end of the Little Ice Age (Hughes, 2014). In parts of the Alps immediately to the north of the Mediterranean basin, late Holocene glaciers were larger than earlier Holocene glacier advances (Hormes et al., 2001; Goehring et al., 2012). Thus, the Little Ice Age represents an important glaciological period for our current interglacial. The fact that glaciers were also commonplace in the Mediterranean mountains in the Little Ice Age has important bearing on our view of glaciation through the Quaternary and suggests that glaciers are likely to have been present in the mountains of this area in all but the warmest interglacials.

Hughes (2014) provides a comprehensive review of the evidence for Little Ice Age glaciers in the Mediterranean mountains. However, this was a descriptive review of the geography of these glaciers and did not include a deeper synthesis of the climatic significance of these glaciers. The paper presented here tackles this issue and provides a new analysis of the climatic significance of selected glacier sites in the western and eastern Mediterranean mountains during the Little Ice Age.

Most Mediterranean glaciers have retreated significantly over the past 100 years, some retreating in status from small glaciers to very small glaciers to ice patches, buried permafrost patches or simply no ice at all. In most areas the modern snowline is above the highest peaks (Fig. 1). However, the fact that some glaciers still persist despite strong climate warming is intriguing and needs explanation, especially in order to understand prospects for the future of glaciers in this region. This paper aims to 1) provide a summary of the evidence for Little Ice Age glaciers in the Mediterranean mountains; 2) provide a new examination of the relationship between glaciers and climate during the Little Ice Age at a two key areas in the Mediterranean - the High Atlas, Morocco, in the west, and the western and southern Balkans, Montenegro/Albania/Greece, in the east; 3) establish patterns of change and compare and contrast the glacier histories of all areas and relate this to wider regional climate change patterns across the Mediterranean and neighbouring regions. 


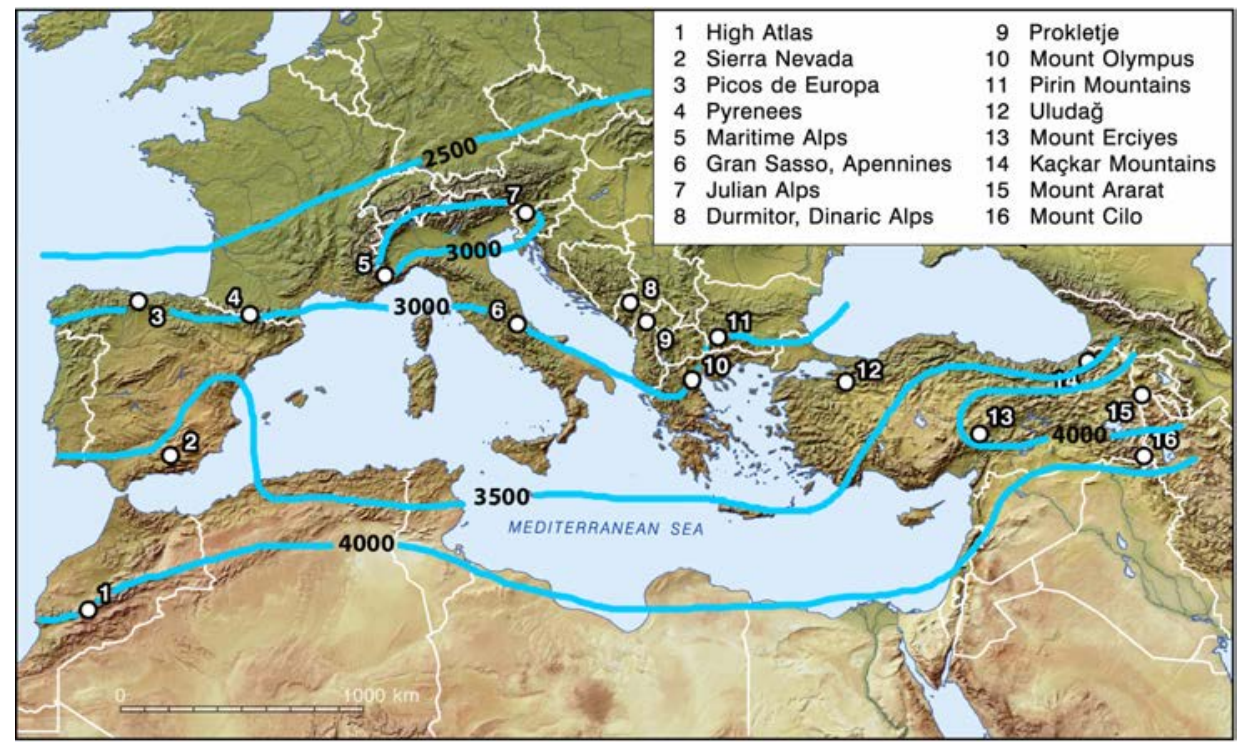

Figure 1. Locations of modern and Little Ice Age glaciers in the Mediterranean mountains. Adapted from Hughes and Woodward (2017) and Hughes (2014). Estimated equilibrium line altitudes (ELAs) are for the present time and are updated from Messerli (1967) based on recent climate and field evidence. The northern ELA isoline of $2500 \mathrm{~m}$ is estimated based on climatic data and field evidence from mountains such as the Tatras in Poland (e.g. Kędzia, 2015). The isolines represent estimated regional ELAs rather than local ELAs and in many cases, especially for the smallest glaciers, topoclimatic effects mean that current glaciers survive below these altitudes.

\section{Little Ice Age and surviving glaciers in the Mediterranean Mountains - a brief review of the evidence and terminology}

The term "Little Ice Age" was originally used by Matthes (1939) to refer to the last 4000 years of climate associated with major glacier oscillations of the Late Holocene (Mann, 2003). Today the term has a more specific definition and is usually used to refer to the recent climatic interval characterised by mean annual air temperatures $\mathrm{c} .1^{\circ} \mathrm{C}$ lower than today spanning the interval between the 16th and mid-19th centuries (Mann, 2003), with the periods 1500-1850 AD specified in (Lamb, 1972) and 1550-1850 by Jones and Bradley (1992). In Europe, the most prolonged cold period of the Little Ice Age was between 1550 and $1750 \mathrm{AD}$ although the period from the 1830s to 1860 s saw some of the coldest summer temperatures (Bradley and Jones, 1993). However, Matthews and Briffa (2005) argue that the glacier advances which characterised the Little Ice Age were forced by increased precipitation in addition to lower temperatures and they argued that the Little Ice Age in the European Alps spanned the period 1300-1950 AD. This paper examines the changing glaciers of the Mediterranean mountains over the past few centuries of the Little Ice Age right up to the present-day. 
The southernmost glaciers in Europe are present in the Pyrenees (France/Spain), Maritime Alps (France/Italy), Apennines (Italy), Italian Southeastern Alps, Julian Alps (Slovenia), Dinaric Alps (Montenegro and Albania) and the Pirin Mountains (Bulgaria). These are small niche glaciers that exist in cirques with strong topoclimatic controls on mass balance. In some areas glaciers have recently disappeared or split into multiple smaller ice patches. In the case of the Corral de Veleta site in the Sierra Nevada, southern Spain, a glacier present in the 1920s was the southernmost in Europe. Today the glacier has gone and only a small patch of permafrost survives (Gomez-Ortiz et al., 2009). In Albania, some small glaciers present nearly a decade ago (Hughes, 2009) were reduced to static snow patches within five years whereas others remained active (Gachev and Stoyanov, 2012) - see later. A summary of the recent distribution of glaciers and ice patches is illustrated in Figure 1.

Most current glaciers in the Mediterranean mountains are very small, covering just a few hectares. Very small glaciers have been defined as $<0.1 \mathrm{~km}^{2}$ by Colucci and Guglielmin (2015) and $<0.5 \mathrm{~km}$ by Huss and Fischer (2016). In fact, the only current Mediterranean mountain glaciers with a surface area $>0.5 \mathrm{~km}^{2}$ are the Maladeta glacier in the Pyrenees, which covered an area of $0.54 \mathrm{~km}^{2}$ in 2000 (Chueca Cía et al., 2005) and several glaciers in the high mountains of Turkey, the largest being the ice cap on Mount Ararat at $7.28 \mathrm{~km}^{2}$ (Azzioni et al., 2017). Very small glaciers $\left(<0.5 \mathrm{~km}^{2}\right)$ are important components of the cryosphere because today these account for more than $80 \%$ of the total number of glaciers in mid- to low-latitude mountain ranges (Huss and Fischer, 2016). Kuhn (1995) provides a useful overview of the nature of very small glaciers including their mass balance and dynamic regime. Very small glaciers are by definition ice bodies that display evidence of movement and internal deformation. Other terms such as niche glacier or wall-glacier have also been applied in the literature. Niche glaciers have been described in numerous papers, although Evans (2006) noted inconsistencies in the application of 'cirque glacier' and 'niche glacier' in the glacier inventories of European Alps. Some authors distinguish between glacierets and glaciers (Grunewald et al., 2006; Gachev and Stoyanov, 2011). However, again this is sometimes an arbitrary distinction like the separation of cirque glaciers from niche glaciers. Kumar (2011) defined glacierets as "very small glaciers or ice masses of indefinite shape in hollows and have little or no movement for at least two consecutive years... sometimes, it is also termed as a dead glacier". However, many very small glaciers are far from dead and continue to survive as dynamic ice masses year-on-year despite very large inter-annual variations in mass balance (e.g. Hughes, 2008).

Static ice bodies are not real glaciers and should instead be termed 'ice patches'. Serrano et al. (2011) defined two types of ice patch - one originating from previously dynamic glacier ice and another originating from a snow patch. The relationships between very small glaciers and ice patches (and indeed snow or firn patches) are obviously very close, since it is a relatively small matter of scale that determines whether an ice body has sufficient mass to move under its own weight (Ballantyne, 1994; Kuhn, 1995; Shakesby, 1995). When considering Little Ice Age glaciers in the Mediterranean mountains, it is inevitable that many sites will be at the cross-over between very small glaciers and ice/snow (firn) patches. Thus, attention to the geomorphological detail is important when examining both current and Little Ice Age ice and snow landforms in these mountains. 
Whilst a variety of terminologies are used to describe small glaciers the most important criterion that distinguishes true glaciers from snow and ice patches is the movement of ice under gravity. In contrast snow patches or ice patches are largely static. Without regular monitoring other clues are needed to determine whether an ice mass is dynamic. In the Sierra Nevada (USA) Raub et al. (1980) separated 497 'glaciers' from 847 'small perennial ice masses' with glaciers being defined as ice masses having a bergschrund or crevasses; visible snow, firn or ice of different years; and/or moraines. The 847 'small perennial ice masses' was updated to 788 'small ice bodies that do not meet the definition of a glacier' in Raub et al. (2006; although the data was from the early 1990s). In Montenegro, Hughes (2007) argued that visibly deformed convex bands of sediment-rich ice on the lower ice surface were consistent with variations in ice velocity across the glacier, with the fastest flow away from the ice margins. Sedimentological characteristics of sediment ridges that bound an ice mass can also help determine whether clasts have undergone active transport under a dynamic glacier. This is important for separating pronival ramparts from true moraines (e.g. Shakesby and Matthews, 1993).

In addition to what defines a glacier at small spatial scales, there are complexities regarding their composition since small glaciers can become overwhelmed by rock debris and morph into rock glaciers (Morris and Olyphant, 1992). In other circumstances rock glaciers do not originate from retreating glaciers but instead are a results of rock/ice admixtures emanating from talus and are truly periglacial features (e.g. Barsch, 1996). Similar small-scale feature are known as protalus lobes (González García et al., 2016). However, the definition of rock glaciers and related features has often been contradictory. Permafrost is the primary condition for rock glaciers, although the deforming ice/debris may be of both glacial and periglacial origin (Berthling, 2011); this is the definition used here. Rock glaciers and their origin are a very relevant issue for any study of Little Ice Age glaciers in the Mediterranean mountains since the relationship between rock debris and snow accumulation is sometimes closely interwoven in the cirques of these mountains as both paraglacial and tectonic factors combine to produce complex cirque geomorphologies (e.g. Hughes et al., 2014). Thus, whilst this paper focuses on Little Ice Age glaciers of the Mediterranean mountains it cannot ignore rock glaciers and, where evident, these are discussed in tandem with the glacier record.

\section{Methodology}

\subsection{Study sites}

This paper presents findings from two key areas from the Mediterranean: the High Atlas in Morocco in the west and the western and southern Balkans (Dinaric Alps, Montenegro/ Albania, and Pindus Mountains, Greece) in the east.

\subsection{Geomorphological mapping}

The geomorphology of the high cirques of Montenegro, northern Albania, northwest Greece and the Toubkal area of the High Atlas have been the subject of ongoing research for author and collaborators over the last two decades. Most cirques have been visited on foot in the summer months. Observations of moraines and associated glacial and 
periglacial landforms have been mapped in detail and in some cases sedimentology of sediment ridges has been undertaken in order to test whether ridges are pronival ramparts or moraines (e.g. Hannah et al., 2017).

Observations of the state and occurrence of late-lying snow have been made in late summer and early autumn in most areas although often this has not been systematic and consistent year-on-year. Consequently, other sources are required to validate the presence or absence of perennial snow. This sometimes includes local knowledge, especially for the High Atlas, although more robust data are now available through historical satellite imagery. The end of the melt season are usually considered to be September and imagery from this month was sought for all sites from a range of sources including Google Earth.

In some cases the ages of moraines have been estimated using lichenometry. This data is available for several sites in the Montenegro and Albania (e.g. Hughes, 2007, 2010; Wilkinson, 2011). However, for Greece and the High Atlas the age of the highest cirque moraines has not been tested using lichenometry. Instead, soil surface weathering has been the main tool of age discrimination (Hughes, 2004; Hannah et al., 2017). The most robust assessment of landform age has been where glaciers and late-lying snowfields are still present, such as in Montenegro, Albania and Morocco. In Greece, this has been provided by recent observations reported by Styllas et al. (2015) who also present an analysis of historical air photographs from Mount Olympus.

\subsection{Climate modelling}

A simple degree-day model was used to calculate the amount of accumulation required to sustain glaciers at the sites in Morocco and Greece. The degree-day model is based upon the notion that glacier melting occurs when air temperatures 1-2 $\mathrm{m}$ above the glacier surface are above the melting point $\left(0^{\circ} \mathrm{C}\right)$. The total melt over a period is therefore proportional to the sum of positive temperatures, i.e. the positive degree-day total. The annual snow accumulation required at the equilibrium line altitude (ELA) to balance melting equals the sum of daily snow melt, using a degree-day factor. Braithwaite (2008) found that degree-day factors for snow on 66 glaciers worldwide had averages of $3.5 \pm 1.4$ and $4.6 \pm 1.4 \mathrm{~mm}^{\text {day }}{ }^{-1}{ }^{\circ} \mathrm{K}^{-1}$ in low- and high-accumulation conditions, respectively, with an overall mean of $4.1 \pm 1.5 \mathrm{~mm}$ day $^{-1}{ }^{\circ} \mathrm{K}^{-1}$. The degree-day factor for snow varies depending on the relative importance of individual components of energy that provide the overall energy for melt (Hock 2003). Whilst this is difficult to predict for palaeoglaciers, such as those from the Pleistocene, for recent glaciers such as those in the Little Ice Age, modern observations of snowpack behaviour (including observations of sublimation and the presence/absence of perennial snow) as well as knowledge of the current and recent climate can help constrain the approach.

Degree-day modelling has the advantage that it is easy to apply using minimal meteorological data compared withenergy balance modelling. In addition, for very small glaciers like those present in the Mediterranean mountains, melt-modelling of snow accumulation is preferred to the well-established empirical relationships between climate variables at glacier ELAs such as Ohmura et al. (1992). This is because the concept of the ELA often difficult to apply to such small glaciers since these frequently experience inter-annual negative or positive mass balance over the entire glacier surface (Hughes, 2008). The Ohmura et al. (1992) dataset 
is also based on glaciers that are all much larger than $1 \mathrm{~km}^{2}$, and includes ice caps, valley glaciers and large cirque glaciers. Furthermore, Braithwaite (2008) used a degree-day model to demonstrate that the data underlying the single empirical curve of Ohmura et al. (1992) relating summer temperature and winter balance + summer precipitation is in fact better described by multiple curves, depending on the region. These different regional relationships are effectively determined by different annual temperature ranges (see Hughes and Braithwaite 2008).

\section{High Atlas, Morocco}

Today in the High Atlas, Morocco, there are no glaciers and snowfields are only semipermanent, with snow melting entirely in some exceptional summers. However, there is evidence of niche glaciers and permanent snowfields in the High Atlas as recently as the last century. This is revealed in both historical maps and written accounts as well as by geomorphological evidence. Joseph Thompson climbed to Tizi Likemt in September 1888 and noted that "Even at that late time of year we found ourselves among wreaths of snow" (Thompson, 1889, p. 462). Most instances of snowfall in the Atlas Mountains are associated with northerly air masses. Peyron (1980) found that for 52 snowfall events between 1950 and $1962,56 \%$ were associated with polar air incursions (20\% with a polar maritime origin, $12 \%$ with a polar continental origin, $24 \%$ without precise polar origin), $18 \%$ were associated with cold fronts delivering Arctic air, 14\% were from Atlantic depressions off Portugal tracking west to east over Iberia, $8 \%$ associated with conflicts between polar air and tropical continental air masses and just $4 \%$ associated with perturbations of Saharan air masses.

The classic documented site of permanent snow is below the northern cliff of the Tazaghart plateau (Hughes, 2014; Hannah et al., 2016). A perennial (now semi-perennial) snowfield occupies a steep gully in these cliffs and has been noted in several maps. For example, this 'névé permanent' is marked on topographic maps dating to the 1940s (US Army Map Service 1943) as well as the 1994 topographic map (Ministere de l'Agriculture et de la Mise en Valeur Agricole, 1994). The feature was originally marked on the detailed 1:20,000 1937 map of the Toubkal Massif presented in Delhaye (1938), which is reviewed in Dusserre (2009). Longlasting snow fields (neiges éternelles) of the Tazaghart and nearby areas were also mentioned by Dresch (1941, p. 577). More recently, the Tazaghart 'névé permanent' is noted in Smith's (2004) trekking guide to the High Atlas. Today, the feature is more likely to be semi-permanent with locals suggesting that it disappears in some exceptional summers. In the Tignousti Massif (3819 m a.s.l.) in the central High Atlas, Peyron (1980) noted that small snow patches can persist into October buried under debris cover then overlain by the following winter's snow.

The lower end of the snowfield is bounded by sediment ridges (Figs. 2 and 3). Hannah et al. (2017) argued that the presence of striated clasts and the fine-grained matrix of the sediment ridge is consistent with subglacial abrasion and clast crushing under a dynamic ice mass (Fig. 3). The ice mass that produced this ridge would have covered a total area of c. 1.49 hectares $\left(14,900 \mathrm{~m}^{2}\right)$. Whilst the Tazaghart glacier was very small, dynamic ice bodies have been observed covering just 1-5 hectares $\left(0.01-0.05 \mathrm{~km}^{2}\right)$ in marginal settings in other Mediterranean mountains (e.g. Grunewald and Scheithauer, 2010; Hughes, 2009, 2010). In September 2012 the snowfield was over 6 times smaller than this and covered an area of just 0.2345 hectares $\left(2345 \mathrm{~m}^{2}\right)$. The lack of any soil development suggests a recent age for 
the moraine. This, and the presence of the 'névé permanent' on several 20th century maps suggests that the moraines were formed by a small glacier during the Little Ice Age. However, the timing of its transition to a static and semi-perennial ice/snow patch is unclear.

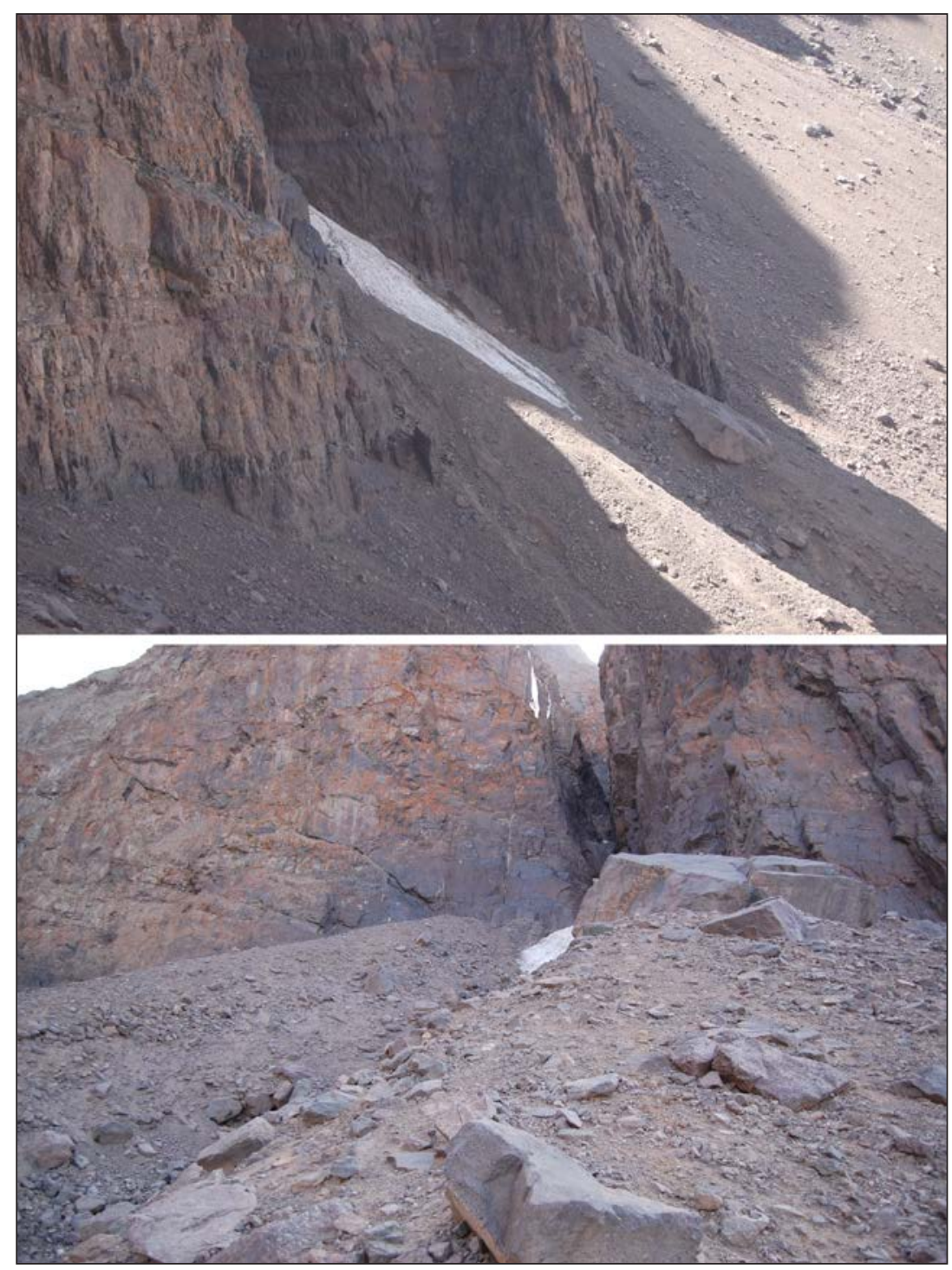

Figure 2. The 'névé permanent' below the northern cliffs of Tazaghart in the High Atlas, Morocco. The top photograph is taken from the east. The bottom photograph is on the western moraine ridge. This gully was marked as containing permanent snow in several topographic maps, including the 1937 1:20,000 map of Toubkal (Delhaye, 1937). Today the feature is semipermanent, disappearing in some exceptional years, and the bounding moraines are likely to represent the limits of a small Little Ice Age glacier (Hannah et al., 2017). Photograph taken in September 2012 by George Hannah. 


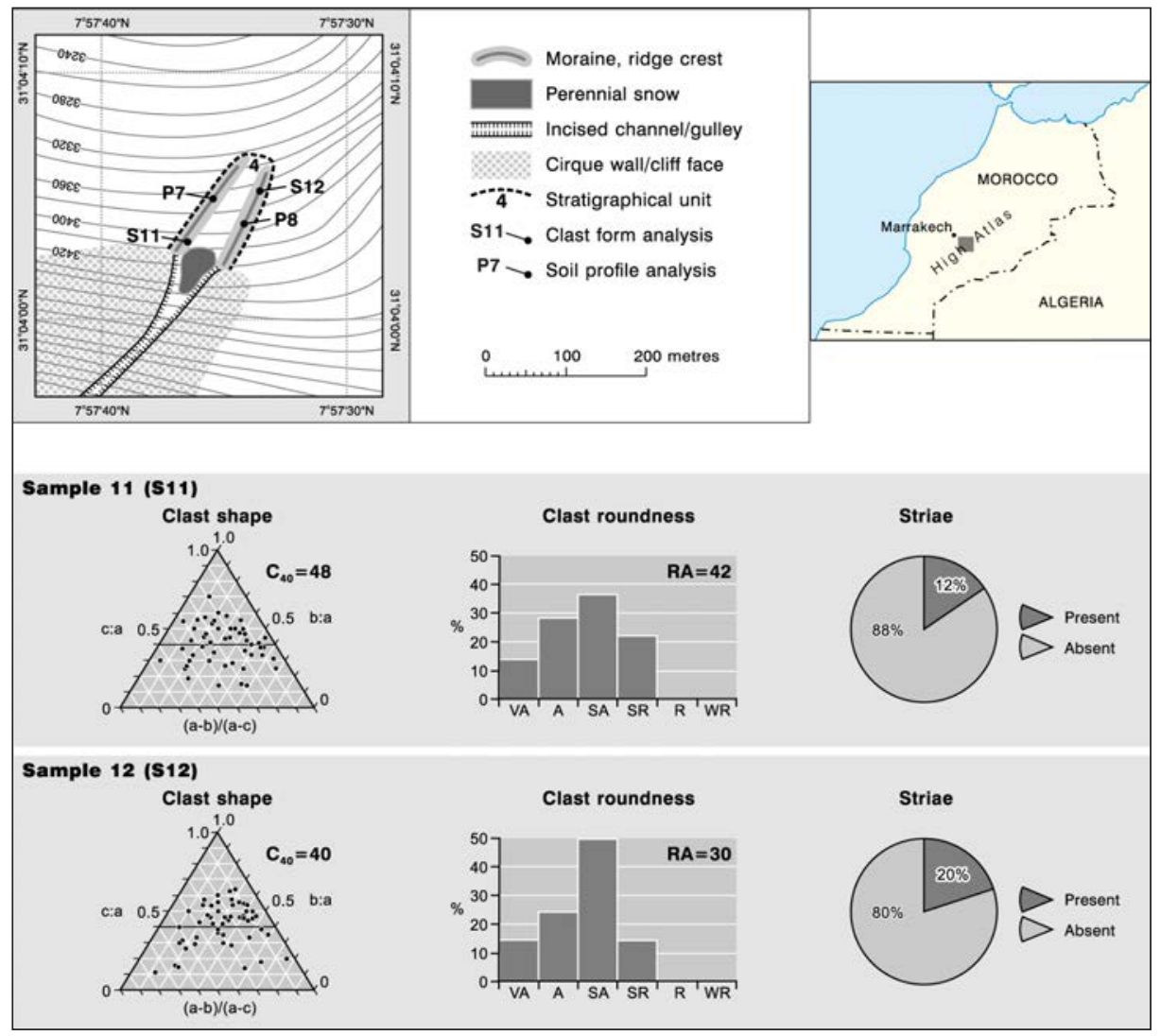

Figure 3. Geomorphological map of the 'névé permanent' site including sedimentological data from the sediment ridges bounding the snowfield. Adapted from Hannah et al. (2017).

It is likely that Little Ice Age glaciers were present in this part of the High Atlas and that these features survived, building moraines at these sites, until the mid- $20^{\text {th }}$ century. The niche glaciers and snowfields survived below the regional equilibrium line altitude because of strong local topoclimatic controls, such as shading, avalanching and windblown snow. The disappearance of these glaciers and snow patches in the last few decades (except for one remaining at Tazaghart) coincides with an increasingly arid climate in North Africa since the 1980s (Esper et al., 2007) as well as increasing summer air temperatures.

Several other sites in the Toubkal Massif contain moraines associated with the presence of small recently-active glaciers. The north-facing cirque of Annrhemer (3952 $\mathrm{m}$ a.s.l.) contains boulder ridges that associated with long-lying (semi-perennial) snowfields. The boulder ridges in the cirque are substantial and are present down to c. $3150 \mathrm{~m}$ a.s.l. The former boulder ridges are interpreted as moraines associated with a small cirque glacier. These moraines are situated at higher elevations than moraines 
dated to the Younger Dryas in nearby cirques, which occur at c. $2900 \mathrm{~m}$ a.s.l. (Hughes et al., 2011, Fig. 76.2; Hughes, 2013, Fig. 6; Fink et al., 2012). This and the fact that today the moraines in the northern cirque of Annrhemer enclose some of the longest-lasting snowfields of the High Atlas, hints at formation during the Little Ice Age. If this is the case, then it is possible that Little Ice Age glaciers could have been more widespread in the High Atlas because there are lots of cirque floors and headwalls above the altitudes of the dated Younger Dryas moraines. However, at this site and elsewhere in the high cirques of the High Atlas, further work is needed to test this hypothesis.

Precipitation records in these mountains exist for the Mizane valley, which drains the north side of Toubkal. Here, mean annual precipitation for the 14 year period 1949/50 to $1963 / 64$ was $837.3 \mathrm{~mm}$ at $3200 \mathrm{~m}$ a.s.l. (Neltner Refuge) and $514.6 \mathrm{~mm}$ at $1900 \mathrm{~m}$ a.s.l. (Arroumd village) just $6 \mathrm{~km}$ down-valley (Messerli, 1967, p. 183). This provides a useful

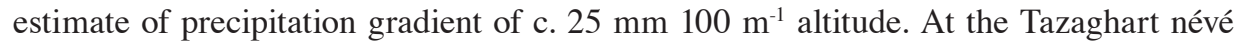
permanent (c. $3440 \mathrm{~m}$ a.s.1.), the modern annual melt is modelled at $5366 \mathrm{~mm}$ (Hannah et al., 2016). Assuming a $1^{\circ} \mathrm{C}$ depression during the Little Ice Age, then it is $4534 \mathrm{~mm}$. Thus, in order to sustain a glacier today or during the Little Ice Age at the Tazaghart névé permanent site then snow accumulation must have been at least four to five times the water equivalent value in direct meteorological precipitation (c. 800-1000 mm). This is only achievable with large avalanche and windblown snow inputs. The historical (and current) observations of perennial snow at this site, and the geomorphological evidence of recent glacier movement, illustrates how local topoclimates can completely decouple glaciers and snow patches from regional climate (e.g. Hughes, 2008, 2009; Colucci, 2016). In the wider Toubkal Massif, Hannah et al. (2016) calculated that at $4000 \mathrm{~m}$ a.s.l. near the highest summits, a mean annual temperature of $c .-1.5^{\circ} \mathrm{C}$ and annual range of $16.1^{\circ} \mathrm{C}$ produces an annual melt of $2780 \mathrm{~mm}$ using a degree-day model that applies an 'average' degree-day factor of $4.1 \mathrm{~mm}^{\circ} \mathrm{C}^{-1}$ day $^{-1}$ (Braithwaite, 2008). Assuming a temperature depression of $1^{\circ} \mathrm{C}$ for the Little Ice Age to $-2.5^{\circ} \mathrm{C}$ at $4000 \mathrm{~m}$ a.s.l., then this produces an annual melt of $2152 \mathrm{~mm}$. Based on the modern precipitation gradient measured in these mountains the precipitation at $4000 \mathrm{~m}$ a.s.l. is estimated to be just over $1000 \mathrm{~mm}$ and thus, glaciers and perennial snowfields require at least twice as much accumulation as the annual precipitation in order to balance melt.

The degree-day factor of $4.1 \mathrm{~mm}^{\circ} \mathrm{C}^{-1} \mathrm{day}^{-1}$ assumes that ablation is dominated by melt as is the case on the average glacier. However, if sublimation is also important in mass balance then the actual melt will be less than this. Sublimation requires a lot of energy and considerably reduces the energy available for melting (Hock, 2003). This could have the effect of significantly lowering surface temperatures over snowfields (and over Little Ice Age glaciers) compared with the surrounding air. This may explain why permanent snow fields were observed in the 20th century and during the Little Ice Age in the Toubkal Massif despite the high summer temperatures and low precipitation of the area. Peyron (1980, p. 244) and Schulz and de Jong (2004) described the occurrence of snow penitents in the Toubkal and M'Goun Massifs, respectively. These ablation features are characteristic of sublimation processes (Lliboutry, 1954). This effect means that the role of air temperature on snow ablation is reduced and in the M'goun Massif 
of the High Atlas up to $44 \%$ of snow ablation is attributed to sublimation in typical winters under dry and cold conditions (Schultz and De Jong, 2004). This potentially means that degree-day modelling underestimates ablation if it assumes that all ablation is via melting associated with positive air temperatures. Whilst degreeday modelling can provide some general insight into potential melt, energy balance modelling incorporating local meteorological characteristics and computation of different energy fluxes at glacier and snow pack surfaces is likely to be necessary in order to fully understand site-specific mass balance (e.g. Wagnon et al., 1999; Gurgiser et al., 2013).

Chardon and Riser (1981, p. 169 and their Fig. 2) identified an active rock glacier at c. $3700-4000 \mathrm{~m}$ in the western cirque of Toubkal (Irhzer Ihkibi Sud). This feature is characterised by a small lobe of large angular boulder debris emanating from the talus slope at the head of the western cirque of Toubkal (for a photograph see Vieira et al., 2017) and is characteristic of a small talus rock glacier (cf. Barsch, 1996) or protalus lobe (cf. González García et al., 2016). Whilst many rock piles and debris accumulations in the lower valleys are more likely to be rock slope failure deposits (e.g. Hughes et al., 2014) or simply moraines (Hughes et al., 2011a), small debris lobes in the highest cirques emanating from talus slopes do resemble small talus rock glaciers or protalus lobes. The Toubkal feature is at the lower boundary of discontinous permafrost, which corresponds to mean annual air temperatures of c. -1 to $-2^{\circ} \mathrm{C}$ (Cheng, 1983; Haeberli, 1985), and could be active today: the $-1^{\circ} \mathrm{C}$ isotherm is estimated to be at an altitude of c. $3900 \mathrm{~m}$ a.s.l. (extrapolated from the mean annual temperature of $19.6^{\circ} \mathrm{C}$ at Marrakech, $466 \mathrm{~m}$ a.s.l. using a lapse rate of $0.6^{\circ} \mathrm{C}$ per $100 \mathrm{~m}$ ). This is supported by ground surface temperature measurements at the Irhzer Ihkibi Sud site on Toubkal recently reported by Vieira et al. (2017), who use this data alongside the geomorphological evidence to argue that permafrost is probably present. Periglacial processes are therefore clearly active today with sporadic and discontinous permafrost still likely to be present in the highest parts of the High Atlas. Other potential small rock glaciers occur at similar altitudes (3650$3900 \mathrm{~m}$ a.s.l.) to the Toubkal rock glacier in the western cirque between Biiguinnoussene (4002 m a.s.1.) and Afella (4043 m a.s.1.). Hannah et al. (2017, their Fig. 1) mapped this feature as a rock slope failure deposit. However, the position of this lobe of rock debris emanating from talus at the headwall of the cirque (Fig. 4) could also be a small rock glacier associated with the retreat of a small Little Ice Age glacier. Here and in the western cirque of Toubkal, as these glaciers retreated they may have been overwhelmed by rock debris leaving the small debris lobes that we see today. The transition from glacier to buried ice patches has been observed at a variety of sites across the Mediterranean mountains, including most famously at Corral del Veleta in the Sierra Nevada, Spain (Palade et al., 2011; Gómez Ortiz et al., 2013, 2014; Palma et al., 2017). However, further work is needed in the High Atlas to confirm whether these are truly rock glaciers or simply rock avalanche deposits. Either way, they could be closely related to retreat of Little Ice Age glaciers since rock avalanches are likely to occur upon glacier retreat toward the headwall. Consequent burial of snow and ice by such debris could form a patch of sporadic permafrost and if actively moving then this could constitute a talus rock glacier (e.g. Palade et al., 2011). 

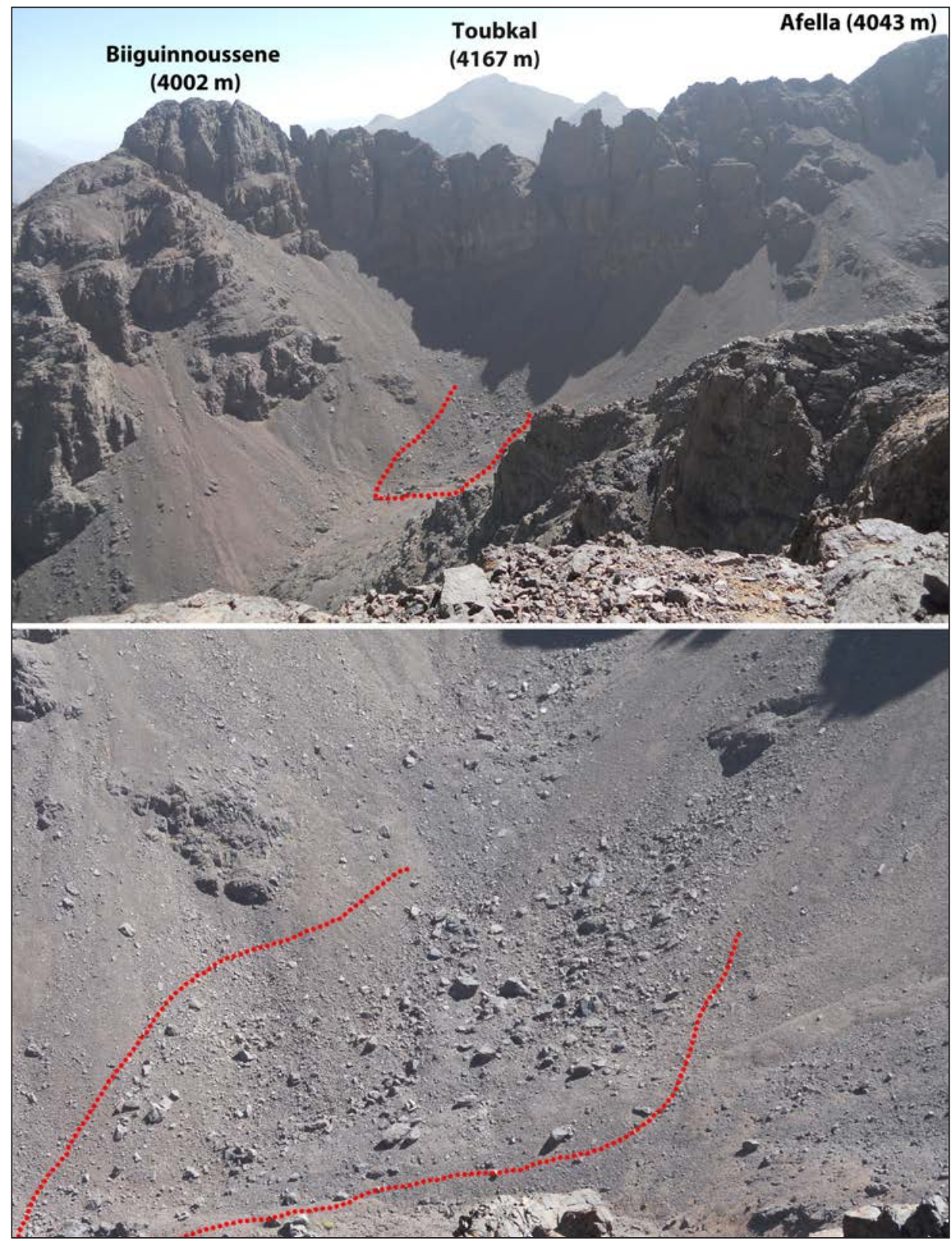

Figure 4. The western cirque between Biiguinnoussene (4002 $m$ a.s.l.) (left peak) and Afella (4043 $m$ a.s.l.) (right, summit out of view). A lobe of rock debris fills the cirque floor and this occurs at a similar altitude to similar features interpreted as active rock glaciers elsewhere (e.g. Chardon and Riser, 1981). However, Hannah et al. (2017, their Fig. 1) mapped the feature as a rock slope failure deposit. Since rock slope failures are also very prevalent in this area (Hughes et al., 2014) further research is required to confirm the origin of the deposit. Photograph taken in September 2012 by George Hannah. 


\section{SW Balkans, Montenegro/Albania/Greece}

The mountains of the western and southern Balkans represent a continuous chain comprising the Dinaric Alps, the Albanian Alps and the Pindus Mountains. Some significant outliers include Mount Olympus (2912 m a.s.l.) in Greece, the highest mountain of this entire region, although this is usually considered separate to the main Pindus chain. This region is important in the context of Little Ice Age glaciers because several modern glaciers have been identified in Montenegro and Albania and permanent snowfields exist on Mount Olympus in Greece. The region also includes some of the wettest parts of the Mediterranean mountains in contrast to the High Atlas explored earlier, which is one of the driest. Gachev et al. (2016) reviewed the evidence for glaciers in the wider Balkans (including Bulgaria) and found that 16 small glaciers still survive in the Durmitor (Montenegro), Prokletije (Albania) and the Pirin (Bulgaria) mountain areas.

In the Durmitor Massif, Montenegro (Fig. 1), the Debeli Namet glacier (Fig. 5) covers several hectares and has an ELA of c. $2150 \mathrm{~m}$ a.s.l. (Hughes, 2008). This glacier has been present in its cirque basin throughout the 20th century (Djurović, 2013). In the 19th century the glacier was only slightly larger than it is today and moraine crests have been dated using lichenometry to c. 1878 AD and 1904 AD (Hughes, 2007).

Djurović (2013) noted that the Debeli Namet glacier has reduced in size at a rate slower than that of other southern European glaciers - despite significant short term contractions in 1998, 2003 and 2007 (Hughes, 2008; Gachev and Stoyanov, 2012). Different authors provide different observations of glaciers size through time (e.g. Hughes, 2008 compared with Djurović, 2013) and this may reflect differences in definition of the glacier margins. Nevertheless, the glacier has clearly maintained a similar size and position over the past 50 years despite proportionally large intrayear fluctuations in area and volume (Hughes, 2008). The topographic niche of this site has been enhanced by the fact that glacier occupies a doline bounded by large moraines (Fig. 5). This topography means that the Little Ice Age ELA of the Debeli Namet differed very little from the present-day ELA. However, at $2130 \mathrm{~m}$ a.s.l. the former ELA was the lowest of all the former Little Ice Age glaciers in the Durmitor massif. At least eight glaciers were present in the Durmitor massif during the Little Ice Age (Fig. 6). The fact that a glacier has survived into the 21 st century at only one site suggests that the other cirques of Durmitor are more sensitive to climate changes than the Debeli Namet glacier (Hughes, 2010). It is likely that the large supply of snow accumulation from avalanche to the Debeli Namet glacier insulates this site from perturbations in regional climate (Hughes, 2008).

There is evidence of small glacier occupation in many cirques in mountains beyond Durmitor, and Hughes et al. (2011b) demonstrated that these post-date larger Younger Dryas glaciers, which were dated using U-series techniques. In the Sinjajevina Massif, moraines ascribed to the Little Ice Age are present in the northern cirques of Gradišta and Torna (2217 m a.s.1.) at altitudes of c. 1850-1925 m a.s.l. (Hughes et al. 2011b). Similar moraine ridges and pronival ramparts are present in the highest cirques of other mountain areas, including several cirques of Kapa Morača (2226 m a.s.1.) and Komovi (2487 m a.s.1.) (Hughes et al., 2011b; Hughes, 2014). 

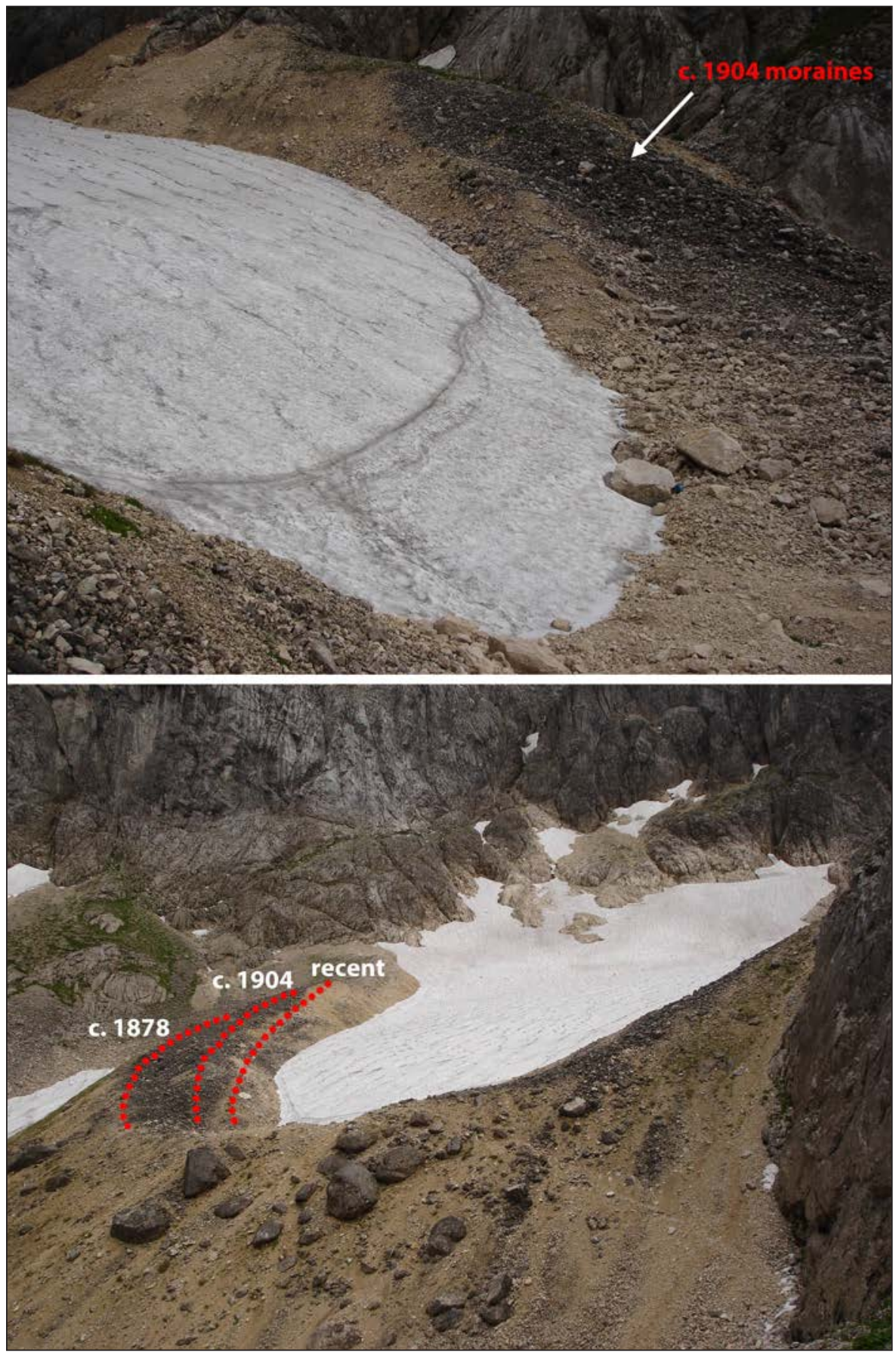

Figure 5. The Debeli Namet glacier in Montenegro. Photograph taken in September 2006 by Philip Hughes. 

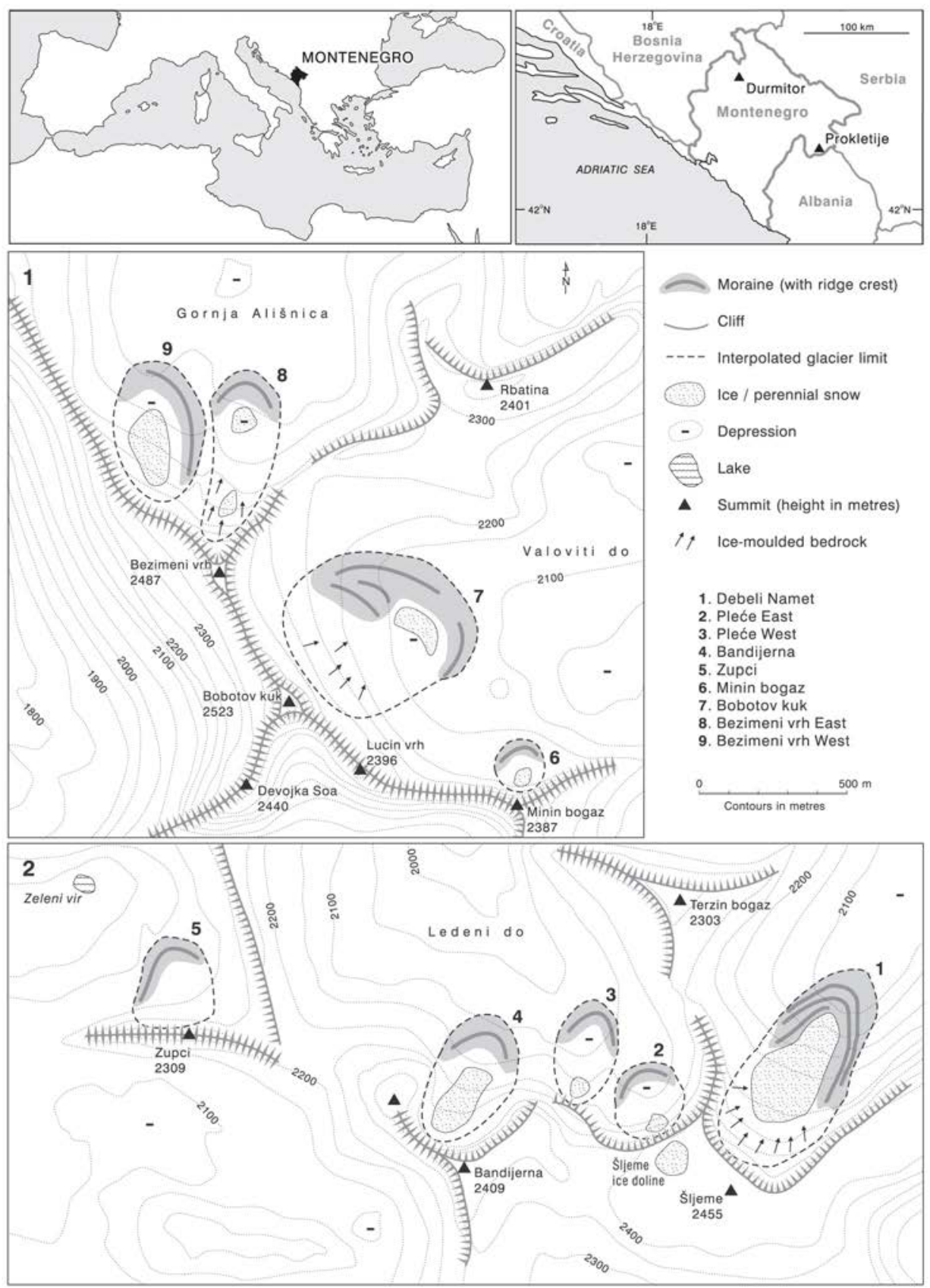

Figure 6. Little Ice Age glaciers in the Durmitor Massif, Montenegro. Site number 6, below Minin bogaz may represent a pronival rampart rather than a moraine (Hughes, 2010). The ice and perennial snow was observed in late-summer and autumn on consecutive years between 2005 and 2008. Adapted from Hughes (2010). 
In the Prokletije Mountains many cirques contain moraines and pronival ramparts that formed during the Little Ice Age. Roth von Telegd (1923) mapped a large perennial snow field in the wide cirque floors to the southwest and northwest of Maja Jezerce (2694 m a.s.1.) (Fig. 7). He also reported the presence of numerous perennial snow patches on the northern slopes of Maja Kolats (2554 m a.s.1.) and Maja Rošit (2522 m a.s.1.) to the north of Maja Jezerce. Alix (1930) noted recent disappearance of glaciers in the Durmitor and Prokletije Massifs. The moraines and ramparts often enclose areas of permanent and semi-permanent snow. On the Albanian side of the Prokletije several small glaciers still survive and Milivojević et al. (2008) and Hughes (2009) identified glaciers in the area of the highest summit Maja Jezerce (2694 m a.s.1.). Three glaciers were reported by Milivojević et al. (2008) whilst a fourth, on the remote eastern face of Maja Jezerce, was reported in Hughes (2009). Glacier areas appear to have oscillated dramatically between 2007-2011 of the 20th century; for example the Maja e Kolacit glacier was 5 ha in September 2007 (Milivojević et al., 2008), 5.9 ha in October 2007 (Hughes, 2009), 8.9 ha in October 2009 (Wilkinson, 2011), yet by October 2011 the feature had all but disappeared (Gachev and Stoyanov, 2012). However, the glaciers on the north face of Maja Jezerce reported by Milivojević et al. (2008) and Hughes (2009) were still active and in good condition in 2011 (Gachev and Stoyanov, 2012). Furthermore, Gachev and Stoyanov (2012) and Gachev et al. (2016) found evidence for several more small ice/snow masses with frontal moraines including two previously unreported glaciers west of Maja Jezerces summit (Maja Jezerce IV and V) and also in a cirque of Maja e Made (2576 m a.s.1.). This suggests that some glaciers are resilient to climate change whereas others are susceptible to decay within only a few years. In the case of the Maja e Kolacit glacier, this was a low gradient ice mass that occupied a large doline floor and was 220-300 m lower than the surviving glaciers on the north face of Maja Jezerce just 2-3 km to the southeast (Fig. 7). It seems that its low altitude, low gradient and more open position with respect to insolation made it susceptible to climate changes despite its large avalanche area to glacier area ratio (cf. Hughes, 2009).

Further south in Greece, there is evidence of perennial snow on Mount Olympus (2912 m a.s.l.) and Styllas et al. (2015) argued that glaciers were present during the Little Ice Age and also at earlier times in the Holocene. Whilst it is in the lee of the Pindus Mountains with regard to westerly atmospheric circulation, the eastern slopes of Olympus are relatively wet with winter precipitation primarily sourced from weather systems originating in the Aegean Sea (Styllas et al., 2015). Today there are no glaciers on Mount Olympus. Nevertheless, semi-perennial snow fields have been observed in the deep northern cirque of Megali Kazarmia which lies directly below the highest top of Mytikas (Fig. 8). Today the temperatureprecipitation ELA (equivalent to regional ELA) lies above this summit but Styllas et al. (2015) used aerial photographs to claim that the ELA was as low as $2410 \mathrm{~m}$ a.s.l. in the 1960s. Well-developed moraines in this cirque were suggested to be Neoglacial (i.e. Holocene) by Smith et al. (1997). This hypothesis is also advocated by Styllas et al. (2015). The evidence from Mount Olympus for the presence of a Little Ice Age 
glacier in Megali Kazarmia is plausible, but this is likely to have been the only site in Greece to have supported a glacier at this time.
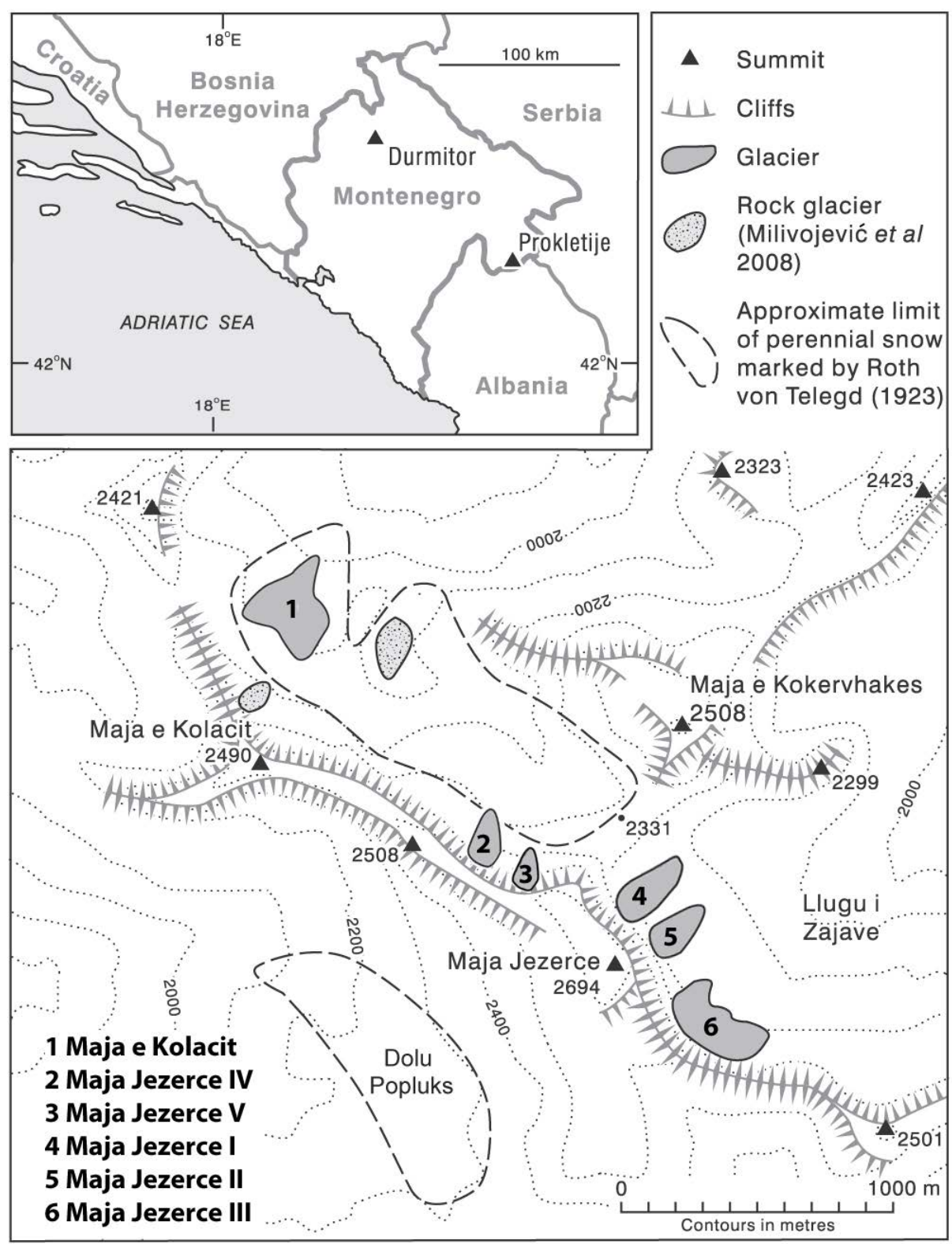

Figure 7. Glaciers in the Prokletije Mountains, Albania, present in the first decade of this century. The Maja e Kolacit glacier was much smaller in 2011 compared with 2009 and is now extinct. Adapted from Hughes (2009) and updated with new data from Gachev and Stoyanov (2012). 


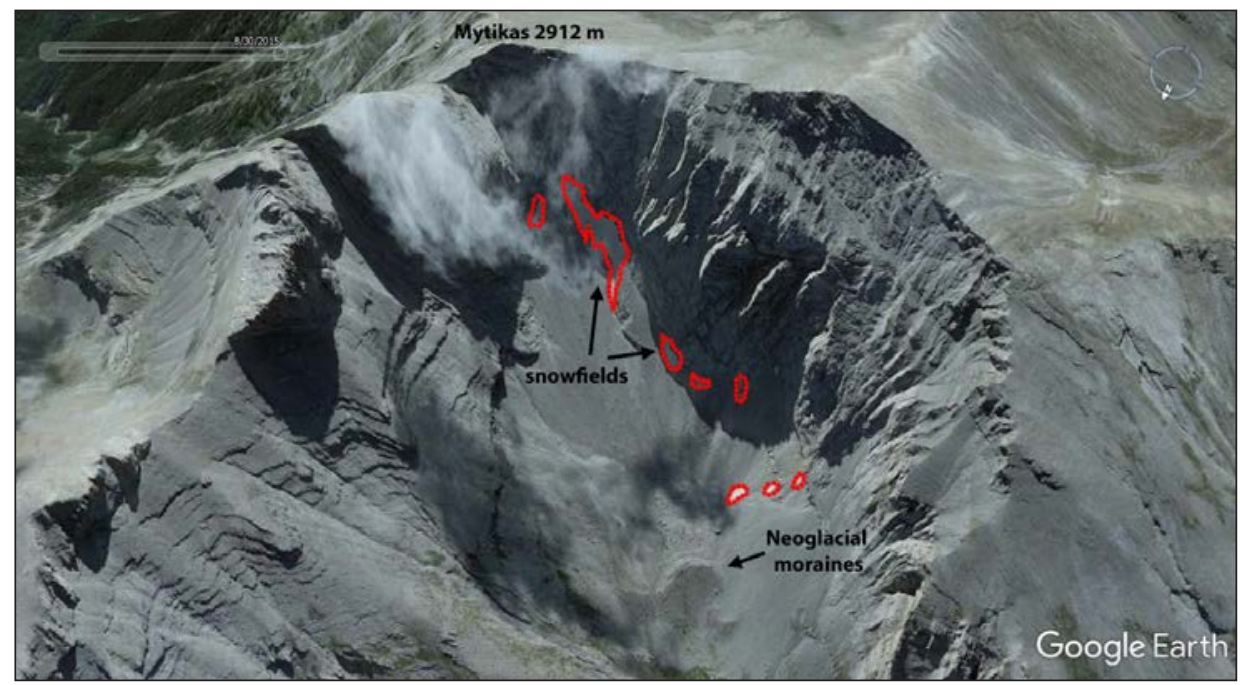

Figure 8. The Megali Kazarmia cirque on the northern slopes the Mount Olympus (highest summit is Mytikas, 2912 m a.s.l.), Greece, showing perennial snow patches and the 'Neoglacial' moraine noted by Smith et al. (1997) and Styllas et al. (2015). This Google Earth image is dated 30th August 2015.

Mount Smolikas (2632 m a.s.l.) is the highest mountain in the main Pindus mountain chain of Greece, and lies to the west of Mount Olympus. Today there are no permanent snowfields on Smolikas, which is $280 \mathrm{~m}$ lower than Mount Olympus. In fact most snowfields have melted significantly by July and rarely survive the summer. This is based on field observations (in 2001 and 2003) and also historical satellite imagery that is now available in Google Earth. Protalus ramparts are evident along the foot of the northern cliffs of the mountain, but these are likely to pre-date the Little Ice Age based on climate modelling (Fig. 9). These, along with the highest cirque moraines nearby, are more likely to be Younger Dryas in age (Hughes et al., 2006). The regional equilibrium line altitude is well above the summit of Smolikas (at c. $3000 \mathrm{~m}$ a.s.l.) (Fig. 1). Hughes et al. (2006b) also calculated that even if summer temperatures were $2^{\circ} \mathrm{C}$ lower during the Little Ice Age in this part of Greece then accumulation of $>5000$ $\mathrm{mm}$ would still be required in order to form the last cirque glaciers. Whilst strong local topoclimatic controls are known to dramatically increase accumulation further north in the Balkans (Hughes, 2009) the case for this happening on Mount Smolikas is doubtful with precipitation values at stations around the mountain being some of the lowest in NW Greece at 1045-1391 mm at altitudes ranging from 950-1350 m a.s.l. (Fotiadi et al., 1999). Based on precipitation data from around the area Hughes (2004)

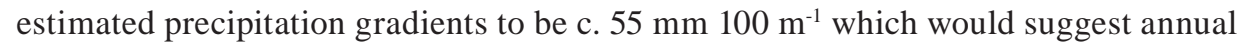
precipitation values of c. 1950-2000 $\mathrm{mm}$ at the ELAs of the last cirque glaciers on Mount Smolikas (2420 m a.s.l.) (Hughes, 2004; Hughes et al., 2006b). The mean annual temperature at this altitude is c. $2.7^{\circ} \mathrm{C}$ based on extrapolation from the mean annual temperature of $14.3^{\circ} \mathrm{C}$ at Ioannina (484 $\mathrm{m}$ a.s.l.) for the $1961-1990$ climate normal period (World Meteorological Organisation 1998). Degree-day modelling suggests 
that $>7000 \mathrm{~mm}$ of snow accumulation is required to offset summer melt, thus requiring a 350\% increase in local accumulation by processes such as avalanching and windblown snow. This contrasts with mountains in Montenegro and Albania where small glaciers survive with summer melting of c. $6143 \mathrm{~mm}$ (Hughes, 2008) which is 200-250\% more than the estimated direct precipitation totals of c. 2500-3000 mm. Recent research has shown that tree rings show potential for palaeoclimatological research (Klippel et al., 2017) and this will be important for understanding snowpack dynamics in the last few centuries here and for other parts of Greece, including Mount Olympus.

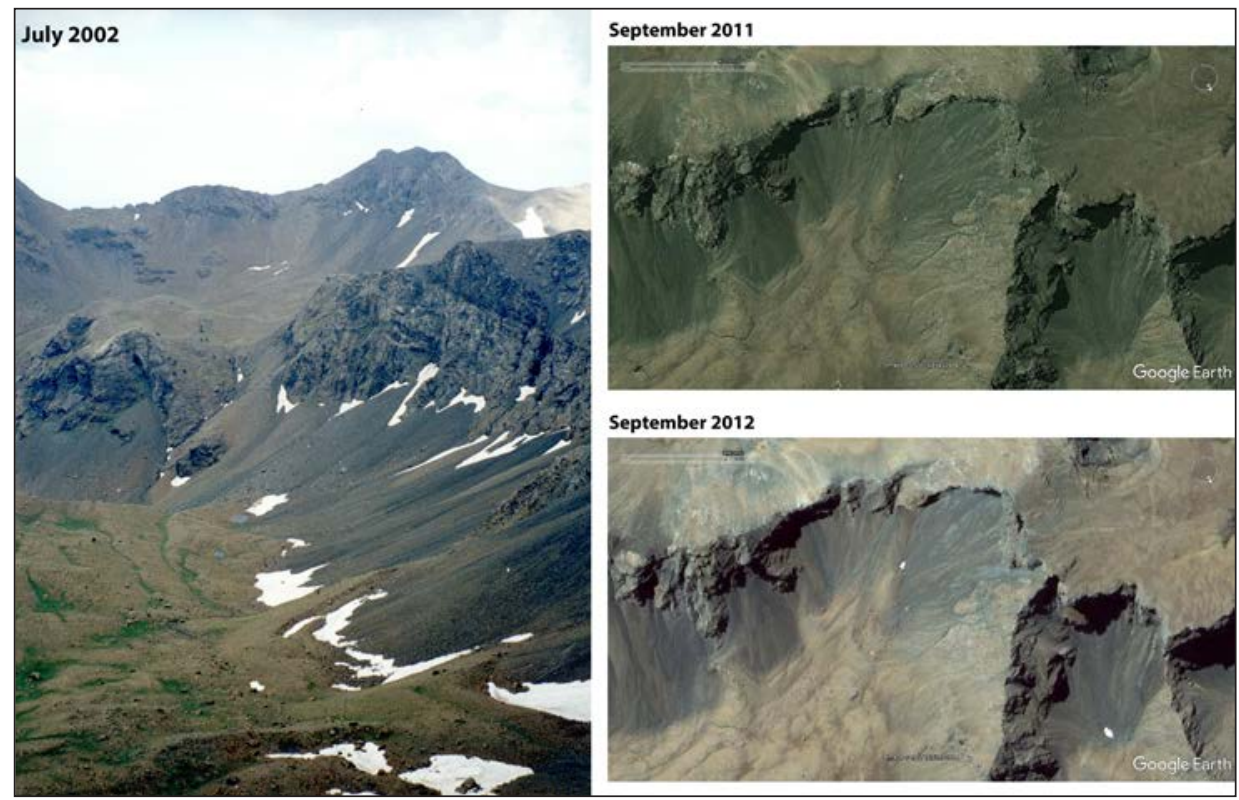

Figure 9. Looking east from the summit of Mount Smolikas in July 2002. Snow does not survive the summer as can be seen in the Google Earth images. Pronival ramparts and moraines in these cirques are thought to be Late Pleistocene in age (Hughes et al., 2006).

The cirques of Mount Smolikas have a much smaller potential avalanche to glacier areas compared with Mount Olympus (compare Figs. 8 and 9). The Smolikas cirques are also formed in ophiolite, a dark-coloured rock that does not produce topography as incised nor complex compared with glaciated karst terrain. This was considered to be a factor explaining contrasting glacial extents and distributions between neighbouring limestone and ophiolite terrains in NW Greece (Hughes et al., 2007) and may also be a factor in explaining the distribution of Little Ice Age glaciers in Greece and the wider Balkans. In fact, snowfields occur on limestone terrains as late as the end of July even in the Peloponnese on mountains much lower than Smolikas and Olympus, such as below cliffs at Mavrolimni on Mount Chelmos (2355 m a.s.l.) where a moraine exists immediately below the modern snowfields (Fig. 10) (see Pope et al., 2017 for a map of this area). However, on this mountain the last glaciers have been shown to date to the 
Late Pleistocene in multiple cirques using cosmogenic exposure dating, conclusively proving the absence of Holocene glaciation in this part of Greece (Pope et al., 2017). Thus, caution must be put on assigning Little Ice Age ages to moraines that enclose latelying snow today without conclusive evidence that glaciers were actually present at that time. Nevertheless, whilst beyond Mount Olympus Little Ice Age glaciers are unlikely to have occurred in Greece, late-lying snowfields were probably much more common at this time even as far south as the Peloponnese.

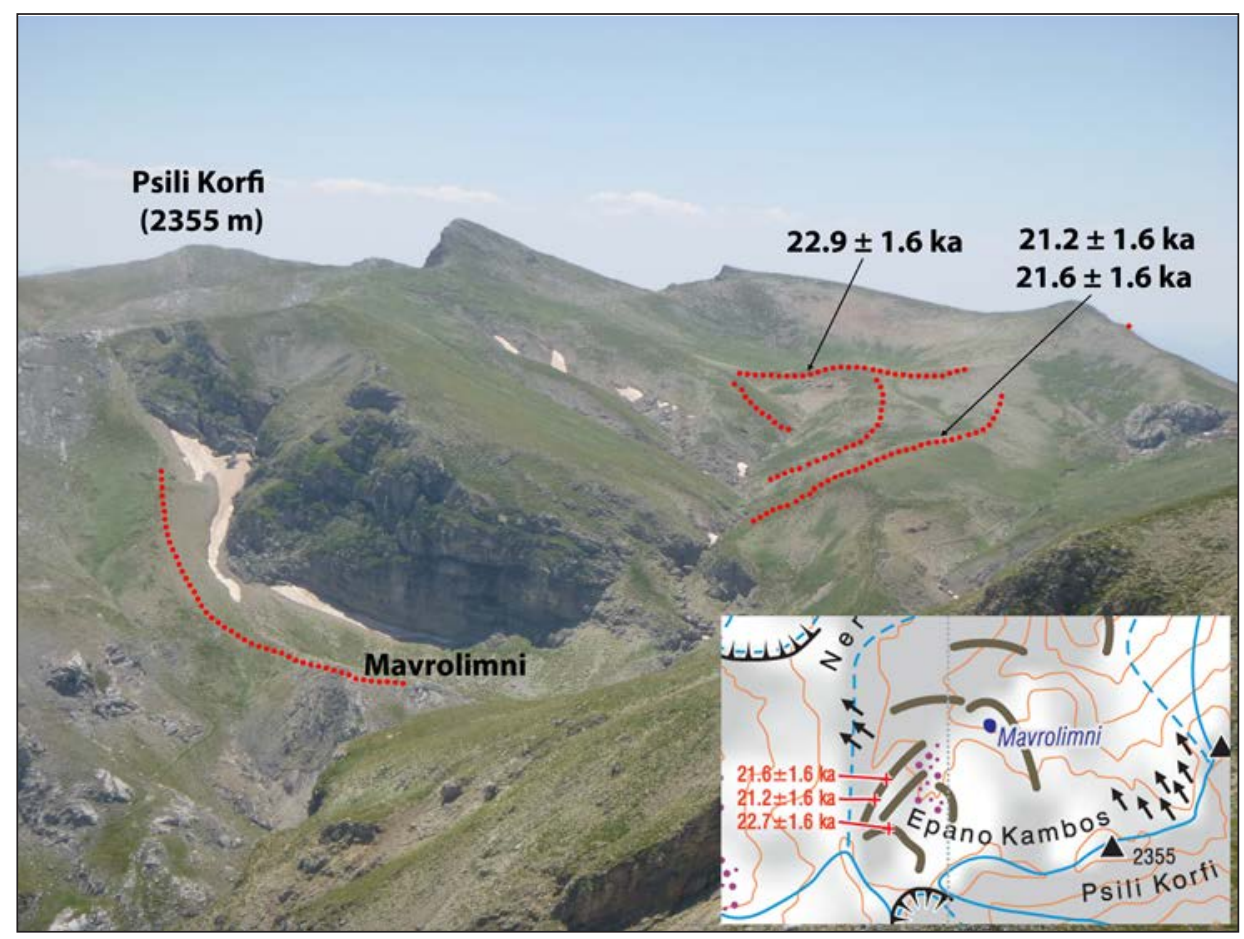

Figure 10. Snow patches above Mavrolimni on Mount Chelmos in the Peloponnese, Greece, in July 2015. These snow patches are bounded by large sediment ridges. However, cosmogenic exposure dating from moraines in the high cirques in the same valley shows that the last phase of glacier occupation was during the Late Pleistocene. Higher in this valley the moraines date close to the global Last Glacial Maximum whereas in other cirques the moraines date to the Younger Dryas (12.9-11.7 ka). No moraines date to the Holocene (Pope et al., 2017).

\section{Little Ice Age glaciers and climate in the Mediterranean Mountains - Discussion}

Glaciers were much more common in the Mediterranean mountains during the Little Ice Age. Whilst only a few glaciers survive today there is evidence that many areas are very close to the threshold for survival of very small glaciers. Huss and Fischer (2016) argue that $52 \%$ of all very small glaciers in Switzerland will completely disappear 
within the next 25 years. This was based on modelling the projected behaviour of 1133 individual glaciers in the Swiss Alps until 2060. However, Huss and Fischer (2016) found that a few avalanche-fed glaciers at low elevation might be able to survive even substantial atmospheric warming. They also found highly variable sensitivities of very small glaciers to air temperature change, with gently-sloping, low-elevation, and debriscovered glaciers being most sensitive. In addition, topoclimatic controls are influenced by the underlying geology. In limestone areas, karstic processes are known to produce complex topography and favouring accumulation and reducing ablation compared with other lithologies, a phenomenon noted across the Mediterranean mountains (Allix, 1930; Barbier and Cailleux, 1950; Nicod, 1968; Hughes et al., 2007). This has been shown to be important for the survival of 23 very small glaciers and ice patches in the Julian Alps (Italy-Slovenia border) in addition to avalanching and the effect of moraines damming the ice features (Colucci, 2016). Very small cirque glaciers can produce large moraines compared with their surface area due to the large amounts of debris supply. Compounding this, very small glaciers in limestone terrains tend to burrow downwards producing their own glaciokarst doline. This phenomenon further promotes moraine-building since there is no proglacial meltwater as it drains below the glacier through the doline floor, a situation common to glaciokarst terrains (Allix, 1930) (Fig. 5). A dramatic example of doline-deepening by karst-nival processes is also evident on the summit of Šljeme directly above the Debeli Namet glacier (Fig. 6) (Hughes, 2010, Fig. 9). Similar nival processes would have been much more widespread during the Little Ice Age, even at lower elevations.

The factors influencing the topoclimatic setting of glaciers has important implications for both predicting the fate of surviving Mediterranean glaciers. The last remaining glaciers in the Mediterranean mountains are in the Pyrenees, the Maritime Alps, the Italian Apennines, the Italian/Slovenian Alps, Montenegro, Albania, Bulgaria and Turkey. The larger glaciers of the Pyrenees and Turkey have undergone significant retreat since the Little Ice Age (Grove, 2004; Çiner, 2004; Chueca Cía et al., 2005; Gonzalez-Trueba et al., 2008; García-Ruiz et al., 2014; Sarıkaya and Tekeli, 2014). However, some of the very small glaciers of the Mediterranean mountains were also very small in the Little Ice Age too. For example, in Montenegro, the Debeli Namet glacier in the Karlica cirque has experience little change beyond its large moraine front in the last 150 years (Hughes et al., 2007; Djurovic, 2013). The site was drawn by Allix (1930, Fig. 3) and photographed by Nicod (1968, Photo I), the latter author noting the 'belle moraine de névé'. Essentially this glacier has oscillated within its self-generated hollow in response to any climate changes. Similar examples include the Maja Jezerce glaciers in Albania (Hughes, 2009) and many of the glaciers of the Julian Alps on the Italy-Slovenia border (Colucci et al., 2016). The same is true for the very small glaciers in the Pirin, Bulgaria which have oscillated within the bounding cirque moraines within the last few decades (Grunewald et al., 2006, 2012; Gachev, 2011). The common factor in producing these moraine morphologies are because the glaciers and snow-firn patches are avalanche-fed and occur in karstic terrain, the latter also promoting the former. Sustained rotational flow within these bounding moraines further deepens the hollow and the size of the bounding moraines. However, the effect is likely to be size-dependent 
with small doline-moraine hollows more likely to be decoupled from regional climate whereas larger lower-gradient glaciers that occupy larger dolines are more prone to decay, such as the Maja e Kolacit glacier in Albania (see earlier).

The resilience of avalanche-fed glaciers in karstic terrain appears to suggest that despite climatic warming these types of very small glaciers are able to survive, decoupled from regional climatic changes. However, whilst this is the case for some glaciers it is clearly not the case for all. For example, in Greece why do we not have any glaciers on Mount Olympus despite the Megali Kazarmia cirque clearly being avalanche-fed and in limestone karstic terrain? The answer is partly likely to lie in the amounts of direct precipitation associated with the surviving glaciers, since greater snowfall further promotes avalanching snow. The glaciers of the Dinaric Alps are associated with some of the wettest conditions of the Mediterranean mountains. However, this is contradicted by the survival of the Pirin glaciers in Bulgaria and other factors must be responsible here. Cirque floor altitudes, and the especially the altitudes of the break of slope at the backwall-cirque floor, are likely to play a role in whether glaciers have survived since the Little Ice Age and also whether they survive future warming. Cirque floor altitudes are inherited from Pleistocene glacial erosion. In some cases even Late Pleistocene glaciers simply reoccupied cirques generated in earlier glaciations with smaller "underfit glaciers" (Bathrellos et al., 2017). The obvious fact is that higher cirques will promote modern glacier survival compared with lower cirques. However, this means that that modern glacier survival is more likely in areas where Pleistocene ELAs were higher, since cirque floors are higher and air temperatures are colder resulting in less summer melt. This paradox explains why glaciers survive today on Mount Vihren in Bulgaria and not on Mount Olympus in Greece, since cirque floors are $100 \mathrm{~m}$ higher on Vihren (2400 m a.s.1.) compared with Olympus (2300 m a.s.1.). This is compounded further by the latitudinal difference between these areas. The strength and altitude of Pleistocene glacier erosion can therefore be important in some cases for the survival of very small cirque glaciers in addition to local topoclimatic controls such as avalanching snow.

Glacier response to climate change is not uniform since glaciers behave differently in different climatic regimes. For example, cold and dry glaciers are less sensitive to a change in air temperature than warm and wet glaciers (Braithwaite and Raper, 2007). This is important because it means that Little Ice Age glacier advances would have been favoured in wet mountain areas since wet-cold glaciers are more sensitive to a $1^{\circ} \mathrm{C}$ drop in temperature than cold-dry glaciers. Glaciers in wetter areas are also more prone to avalanching snow than those in drier areas, and this would have been especially important for the prevalence of very small glaciers at cirque backwalls during the Little Ice Age. This would produce significant expansion of glacier numbers in the wettest Mediterranean mountains such the Cantabrian Mountains and the Dinaric Alps. Conversely, wet-cold glaciers are also more sensitive to a $1^{\circ} \mathrm{C}$ rise in temperature than cold-dry glaciers. This means that the large numbers of glaciers likely to have formed in the wetter mountain regions would have also been prone to rapid retreat. This is evident in the documented cases of glaciers such as on Mount Triglav in Slovenia. However, once glaciers in these areas reach the cirque backwall then local topoclimatic controls dominate decoupling these glaciers from the regional climate. In some cases where mountains are at relatively 
low elevations, like the Debeli Namet glacier in Montenegro, glaciers never expanded far beyond this state even during the Little Ice Age. Whilst cold-dry glaciers may be less sensitive to temperature rise than cold-wet glaciers, it is still evident that glaciers have also retreated throughout the driest parts of the Mediterranean mountains, such as in southern Spain and Turkey. These types of glacier are also more likely to become overwhelmed by rock debris compared with wetter areas, morphing into rock glaciers or buried permafrost patches. This is observed in High Atlas in Morocco, the Sierra Nevada in southern Spain, and also the Taurus Mountains in Turkey; all dry-cold areas at high altitude with evidence of recent rock glacier activity.

In summary, it is clear that glaciers have dramatically reduced in size across the Mediterranean since the Little Ice Age. The patterns of glacier expansion during this cold interval and subsequent retreat are complicated by the sensitivities of glaciers to different climatic regimes. Future prospects for larger glaciers still present in the Mediterranean mountains are most certainly one of retreat, especially given projections of a warmer global climate (IPCC, 2013). However, projections of precipitation in the Mediterranean are more complex with drier winters suggested for the southern Mediterranean and wetter winters for the north. As glaciers retreat to cirque headwalls they become more dominated by local topoclimatic controls, especially avalanching snow. This effect causes all glaciers to become less sensitive to regional climate changes, but the effect is especially pronounced in areas of high snowfall. So, whilst the overall picture is one of glacier retreat, very small glaciers in the wettest mountains of the Mediterranean may well survive in a scenario of a warmer and wetter climate.

The extent and timing of Little Ice Age glacier and associated snowpack expansion during the Little Ice Age is very likely to be influenced by the North Atlantic Oscillation (NAO). In particular, variations in the changing patterns of NAO through this period (Luterbacher et al., 2001) would have had different effects on winter precipitation and summer temperatures, both the drivers of glacier mass balance. The pattern of NAO is known to cause differences to the patterns of atmospheric circulation in the Mediterranean region, especially the paths of winter depressions versus blocking anticyclones. Testing relationships between NAO variations to Little Ice Age glacier behaviour in the Mediterranean mountains will require precise dating of the glacial events. Moraines can be dated to determine the maximum extent of Little Ice Age glaciers as well as subsequent readvance or standstill phases. Techniques such as lichenometry are suitable for this as are other relative-age surface dating techniques such as Schmidt Hammer Exposure Dating (Matthews and Owen, 2008; Tomkins et al., 2015), although the efficacy of this technique on limestone, which is a common lithology in the Mediterranean mountains, is untested. Cosmogenic exposure dating is also potentially suitable, although the errors associated with this technique mean that dating surfaces of just a few hundred years is problematic though not impossible, with recent papers reporting success in dating young glacial surfaces with ${ }^{10} \mathrm{Be}$ (cf. Schimmelpfennig et al., 2014; Kirkbride et al., 2015). Indirect dating of glacial events using radiocarbon dating of lake sediments in alpine areas is likely to be useful and potentially more precise than dating moraines themselves (e.g. Wilkinson, 2011). This is likely to be a future research priority for understanding 
wider environmental change and relating this to glacier changes in the mountains during the Little Ice Age.

Glaciation in the Mediterranean mountains is also known to have been a major influence of river regime in the Pleistocene (Woodward et al., 2008). The expansion of albeit much smaller glaciers in the Mediterranean mountains during the Little Ice Age would have inherently been matched by an expansion of perennial snow and late-lying snowfields. Since glaciers would have been small during the Little Ice Age their effects on erosion would have been modest. Nevertheless, the presence of prolonged snowpack over the Mediterranean mountains during the summers of the Little Ice Age would have had significant effects on downstream fluvial hydrology. In addition to nival processes, broader expansion of periglacial activity during the Little Ice Age in Mediterranean mountain environments (cf. Oliva et al., 2016) would have also had a major impact on catchment hydrology. All of this would have had an effect on river regime, in terms of sediment load as well as discharge. Essentially the melt season would have been prolonged, possibly extending throughout summer meaning that fluvial regimes commonly seen in May-June would have characterised the entire summer. This is likely to have increased erosion and sediment supply at a time when human populations were predominantly rural. These combinations of events coincided with the expansion of the major deltas of the northern Mediterranean, especially in the western and central Mediterranean (Grove, 2001). In addition, Grove (2001) highlights the evidence for increased high-magnitude rainfall and flooding events during the Little Ice Age and the effects on fluvial sedimentation.

\section{Conclusions}

Glaciers were much more common in the Mediterranean mountains during the Little Ice Age even as far south as the Atlas Mountains in North Africa. Most were very small glaciers that have long since disappeared. Larger glaciers in mountains such as the Pyrenees and Turkey retreated through the last century and represent the bulk of the surviving glaciers we see today. However, very small glaciers still survive in several mountain areas, such as the Maritime Alps (France/Italy), Julian Alps (Italy/Slovenia), the Dinaric Alps (Montenegro/Albania), and the Pirin Mountains (Bulgaria). Elsewhere, perennial ice and snow patches still survive and attest to how close some Mediterranean mountains are to supporting small glaciers. Regional equilibrium line altitudes are above the highest peaks, even where glaciers survive today. This is because glaciers are usually facilitated by strong local topoclimatic conditions with avalanche-fed glaciers being the most resilient to climate change. In addition to increased glacier activity, nival processes would have been much more widespread across the Mediterranean mountains during the Little Ice Age. This recent cold interval would have been a major period of landscape change throughout these mountains.

\section{Acknowledgements}

I thank the Associate Editor José M. García-Ruiz for handling this paper. I also thank Marc Oliva and an anonymous reviewer for their very helpful constructive reviews. 
I thank George Hannah and Rose Wilkinson for their work in Morocco and Albania, respectively. In addition, I thank Jamie Woodward for assistance in Montenegro and Morocco, Jeff Blackford in Albania, and William Fletcher in Morocco. I also thank Roger Braithwaite for discussions regarding the degree-day modelling.

\section{References}

Allix, A. 1930. Formes glaciares sur calcaire à plis autochtones. Annales de Géographie 39, 299-305. Azzioni, R.S., Zerboni, A., Pelfini, M., Garzioni, C.A., Cioni, R., Meraldi, E., Smiraglia, C., Diolaiuti, G.A. 2017. Geomorphology of Mount Ararat/Ağri Daği (Ağri Daği Milli Parki, Eastern Anatolia, Turkey). Journal of Maps 13, 182-190. http://doi.org/10.1080/17445647.2017.1279084.

Ballantyne, C.K. 1994. Glaciological constraints on protalus rampart development. Permafrost and Periglacial Processes 5, 145-143. http://doi.org/10.1002/ppp.3430050304.

Barbier, A., Cailleux, A. 1950. Glaciaire et périglaciaire dans le Djurdjura occidental (Algérie). Comptes Rendus des Séances de l'Académie des Sciences, Paris. Juillet-Décembre 1950, 365-366.

Barsch, D. 1996. Rock Glaciers: Indicators for the present and former Geoecology in High Mountain environments. Springer Verlag, Berlin.

Bathrellos, G.D., Skilodimou, H.D., Maroukian,H. 2017. The significance of tectonism in the glaciations of Greece. In: P.D. Hughes, J.C.Woodward (Eds.), Quaternary Glaciation in the Mediterranean Mountains. Geological Society, London, Special Publications 433, 237-250.

Berthling, I. 2011. Beyond confusion: Rock glaciers as cryo-conditioned landforms. Geomorphology 131, 98-106. https://doi.org/j.geomorph.2011.05.002.

Bradley, R.S., Jones, P.D. 1993. 'Little Ice Age' summer temperature variations: their nature and relevance to recent global warming trends. The Holocene 3, 367-376. http://doi. org/10.1177/095968369300300409.

Braithwaite, R.J. 2008. Temperature and precipitation climate at the equilibrium-line altitude of glaciers expressed by the degree-day factor for melting snow. Journal of Glaciology 54, 437-444. http://doi.org/10.3189/002214308785836968.

Braithwaite, R.J., Raper, S.C.B. 2007. Glaciological conditions in seven contrasting regions estimated with the degree-day model. Annals of Glaciology 46, 297-302. http://doi. org/10.3189/172756407782871206.

Chardon, M., Riser, J. 1981. Formes et processus géomorphologiques dans le Haut-Atlas marocain. Revue de Géographie Alpine 69, 561-582.

Cheng, G. 1983. Vertical and horizontal zonation of high-altitude permafrost. Fourth International Conference on Permafrost, Proceedings, pp. 136-141.

Chueca Cía, J., Julián Andrés, A., Saz Sánchez, M.A., Creus Novau, C., López Moreno, J.I. 2005. Responses to climatic changes since the Little Ice Age on Maladeta Glacier (Central Pyrenees). Geomorphology 68, 167-182. https://doi.org/10.1016/j.geomorph.2004.11.012.

Çiner, A. 2004. Turkish Glaciers and Glacial Deposits. In: J. Ehlers, P.L. Gibbard (Eds.), Quaternary Glaciations - Extent and Chronology. Part I: Europe. Amsterdam, Elsevier, pp. 419-429.

Colucci, R.R. 2016. Geomorphic influence on small glacier response to post-Little Ice Age warming: Julian Alps, Europe. Earth Surface Processes and Landforms 41, 1227-1240. http://doi. org/10.1002/esp.3908.

Colucci, R.R., Guglielmin, M. 2015. Precipitation-temperature changes and evolution of a small glacier in the southeastern European Alps during the last 90 years. International Journal of Climatology 35, 2783-2797. http://doi.org/10.1002/joc.4172

Colucci, R., Forte, E., Boccali, C., Dossi, M., Lanza, L., Pipan, M., Gugielmin, M. 2015. Evaluation of internal structure, volume and mass of glacial bodies by integrated LiDAR and ground 
penetrating radar surveys: The case study of Canin Eastern Glacieret (Julian Alps, Italy). Surveys in Geophysics 36, 231-252.

Delhaye, T.J. 1938. La carte du massif du Toubkal au 1/20 000. Hespéris, pp. 181-198.

Djurović, P. 2013. The Debeli Namet glacier from the second half of the 20th Century to the present. Acta Geographica Slovenica 52 (2), 277-301.

Dresch, J. 1941. Recherches sur l'évolution du relief dans le Massif Central du Grand Atlas le Haouz. et le Sous. Arrault et Cie, Maitres Imprimeurs, Tours. 653 pp.

Dusserre, A. 2009. Une étape de la mise en carte de la montagne marocaine (137): le massif du Toubkal au 1/20000. http://mappemonde.mgm.fr/num21/articles/art09105.html.

Esper, J., Frank, D., Büntgen, U., Verstege, A., Luterbacher, J., Xoplaki, E. 2007. Long-term drought severity variations in Morocco. Geophysical Research Letters 34, L17702. http://doi. org/10.1029/2007GL030844.

Evans, I.S. 2006. Glacier distribution in the Alps: Statistical modelling of altitude and aspect. Geografiska Annaler 88A, 115-133. http://doi.org/10.1111/j.0435-3676.2006.00289.x.

Fink, D., Hughes, P., Fenton, C. 2012. Extent, timing and palaeoclimatic significance of glaciation in the High Atlas, Morocco. 21 It International Radiocarbon Conference, Paris, July 2012. Abstract Booklet,Abstract S18-P-348,p.558.http://www.radiocarbon.org/Info/RC_2012_ABSTRACTS_ BOOK.pdf. https://www.escholar.manchester.ac.uk/api/datastream?publicationPid=uk-ac-manscw:218044\&datastreamId=FULL-TEXT.PDF.

Gachev, E. 2011. Inter-annual size variations of the Snezhnika glacieret (the Pirin Mountains, Bulgaria in the last ten years). Studia Geomorphologica Carpatho-Balcanica 45, 7-19.

Gachev, E., Stoyanov, K. 2012. Present day small perennial firn-like patches in the mountains of the western Balkan peninsula. Studia Geomorphologica Carpatho-Balcanica 46, 51-70. http://doi. org/10.2478/v10302-012-0004-0.

Gachev, E., Stoynaov, K., Gikov, A. 2016. Small glaciers on the Balkan Peninsula: State and changes in the last several years. Quaternary International 415, 33-54. https://doi.org/10.1016/j. quaint.2005.10.042.

García-Ruiz, J.M., Palacios, D., Andrés, N. de, Sanjuán, Y. 2014. Holocene and 'Little Ice Age' glacial activity in the Marboré Cirque, Monte Perdido Massif, Central Spanish Pyrenees. The Holocene 24, 1439-1452. https://doi.org/10.1177/0959683614544053.

Goerhring, B.M., Schaefer, J.M., Schlücter, C., Lifton., N., Finkel, R.C., Jull, A.J.T., Akçar, N., Alley, R.B. 2011. The Rhone Glacier was smaller than today for most of the Holocene. Geology 39, 679682. https://doi.org/10.1130/G32145.1.

Gómez-Ortiz, A., Palacios, D., Schulte, L., Salvador-Franch, F., Plana, J.A. 2009. Evidences from historical documents of landscape evolution after Little Ice Age of a Mediterranean high mountain area, Sierra Nevada, Spain (eighteenth to twentieth centuries). Geografiska Annaler 91A, 279-289. http://doi.org/10.1111/j.1468-0459.2009.00370.x.

Gómez-Ortiz, A., Oliva, M., Salvador-Franch, F., Salvà-Catarineu, M., Palacios, D., Sanjosé, J.J., Tanarro, L., Galindo-Zaldívar, J., Sanz de Galdeano, C. 2014. Degradation of buried ice and permafrost in the Veleta cirque (Sierra Nevada, Spain) from 2006-2013. Solid Earth 5, 979-993. https://doi.org/10.5194/se-5-979-2014.

Gómez Ortiz, A., Palacios, D., Palade, B., Vázquez-Selem, L., Salvador-Franch, F., Tanarro, L., Oliva, M. 2013. La evolución glaciar de Sierra Nevada y la formación de glaciares rocosos. Boletín de la Asociación de Geógrafos Españoles 61, 139-162.

González García, M., Serrano Cañadas, E., Sanjosé Blasco, J.J., González Trueba, J.J. 2016. Surface dynamic of a protalus lobe in the temperate high mountain. Western Maladeta, Pyrenees. Catena 149, 689-700. https://doi.org/10.1016/j.catena.2016.08.011. 
González-Trueba, J.J., Martin Moreno, R., Martínez de Pisón, E., Serrano, E. 2008. Little Ice Age glacier advance and current glaciers in the Iberian Peninsula. The Holocene 18, 551-568. https:// doi.org/10.1177/0959683608089209.

Grove, A.T. 2001. The Little Ice Age and its geomorphological consequences in Mediterranean Europe. Climatic Change 48, 121-136.

Grove, J.M. 2004. Little Ice Ages: Ancient and Modern. Volumes I and II. Routledge, London.

Grunewald, K., Weber, C., Scheithauer, J., Haubold, F. 2006. Mikrogletscher im Piringebirge (Bulgarien). Zeitschrift für Gletscherkunde und Glazialmorphologie 39, 99-114.

Grunewald, K., Scheithauer, J. 2008. Bohrung in einen Mikrogletscher. Zeitschrift für Gletscherkunde und Glazialmorphologie 42, 3-18.

Grunewald, K., Scheithauer, J. 2010. Europe's southernmost glaciers: response and adaptation to climate change. Journal of Glaciology 42, 3-18.

Gurgiser, W., Marzeion, B., Nicholson, L., Ortner, M., Kaser, G. 2013. Modeling energy and mass balance of Shallap Glacier, Peru. The Cryosphere 7, 1787-1802. https://doi.org/10.5194/tc-7-17872013.

Haeberli, W. 1985. Creep of mountain permafrost: internal structure and flow of alpine rock glaciers. Mitteilungen der Versuchsanstalt für Wasserbau, Hydrologie und Glaziologie 77, 142 pp.

Hannah, G., Hughes, P.D., Gibbard, P.L. 2017. Pleistocene plateau ice fields in the High Atlas, Morocco. In: P.D. Hughes, J.C. Woodward (Eds.), Quaternary glaciation in the Mediterranean Mountains. Geological Society of London Special Publications 433, 25-53.

Hock, R. 2003. Temperature index melt modelling in mountain areas. Journal of Hydrology 282, 104115. https://doi.org/10.1016/S0022-1694(03)00257-9.

Hormes, A., Müller, B.U., Schlüchter, C. 2001. The Alps with little ice: evidence for eight Holocene phases of reduced glacier extent in the central Swiss Alps. The Holocene 11, 255-265. https://doi. org/10.1191/095968301675275728.

Hughes, P.D. 2004. Quaternary glaciation in the Pindus Mountains, Northwest Greece. PhD thesis, University of Cambridge, $341 \mathrm{pp}$.

Hughes, P.D. 2007. Recent behaviour of the Debeli Namet glacier, Durmitor, Montenegro. Earth Surface Processes and Landforms 10, 1593-1602. http://doi.org/10.1002/esp.1537.

Hughes, P.D. 2008. Response of a Montenegro glacier to extreme summer heatwaves in 2003 and 2007. Geografiska Annaler 90A, 259-267. http://doi.org/10.1111/j.1468-0459.2008.00344.x.

Hughes, P.D. 2010. Little Ice Age glaciers in Balkans: low altitude glaciation enabled by cooler temperatures and local topoclimatic controls. Earth Surface Processes and Landforms 5, 229241. http://doi.org/10.1002/esp.1916.

Hughes, P.D. 2009. Twenty-first Century Glaciers in the Prokletije Mountains, Albania. Arctic, Antarctic and Alpine Research 41, 455-459. http://doi.org/10.1657/1938-4246-41.4.455.

Hughes, P.D. 2013. Quaternary-Pleistocene glacial and periglacial environments. In: J. Schroder, R. Giardino, J. Harbor (Eds.), Treatise on Geomorphology. Volume 8 - Glacial and Periglacial Geomorphology. San Diego, Academic Press, pp. 30-44.

Hughes, P.D. 2014. Little Ice Age glaciers in the Mediterranean mountains. Mediterranée 122, 63-79.

Hughes, P.D., Braithwaite, R.J. 2008. Application of a degree-day model to reconstruct Pleistocene glacial climates. Quaternary Research 69, 110-116. https://doi.org/10.1016/j.yqres.2007.10.008.

Hughes, P.D., Woodward, J.C. 2017. Quaternary Glaciation in the Mediterranean Mountains: A New Synthesis. In: P.D. Hughes, J.C. Woodward (Eds.), Quaternary glaciation in the Mediterranean Mountains. Geological Society of London Special Publications 433, 1-23.

Hughes, P.D., Woodward, J.C., Gibbard, P.L. 2006a. Quaternary glacial history of the Mediterranean Mountains.ProgressinPhysical Geography30,334-364.https://doi.org/10.1191/0309133306pp481ra.

Hughes, P.D., Woodward, J.C., Gibbard, P.L. 2006b. The last glaciers of Greece. Zeitschrift für Geomorphologie 50, 37-61. http://doi.org/10.1127/zfg/50/2006/37. 
Hughes, P.D., Gibbard, P.L., Woodward, J.C. 2007. Geological controls on Pleistocene glaciation and cirque form in Greece. Geomorphology 88, 242-253. https://doi.org/j.geomorph.2006.11.008.

Hughes, P.D., Fenton, C.R., Gibbard, P.L. 2011a. Quaternary glaciations of the Atlas Mountains, North Africa. In: J. Ehlers, P.L. Gibbard, P.D. Hughes (Eds.), Quaternary Glaciations - Extent and Chronology, Part IV - A Closer Look. Amsterdam, Elsevier, pp. 1071-1080.

Hughes, P.D., Woodward, J.C., van Calsteren, P.C., Thomas, L.E. 2011b. The glacial history of the Dinaric Alps, Montenegro. Quaternary Science Reviews 30, 3393-3412. https://doi.org/10.1016/j. quascirev.2011.08.016.

Hughes, P.D., Fink, D., Fletcher, W.J., Hannah, G. 2014. Catastrophic rock avalanches in a glaciated valley of the High Atlas, Morocco: ${ }^{10} \mathrm{Be}$ exposure ages reveal a $4.5 \mathrm{ka}$ seismic event. Geological Society of America Bulletin 126, 1093-1104. http://doi.org/10.1130/B30894.1.

Huss, M.,Fischer, M. 2016. Sensitivity of very small glaciers in the Swiss Alps to future climate change. Frontiers in Earth Science 4 (34). http://doi.org/10.3389/feart.2016.00034

IPCC (Intergovernmental Panel on Climate Change) 2013. Summary for Policymakers. In: T.F. Stocker, D. Qin, G.K. Plattner, M. Tignor, S.K. Allen, J. Boschung, A. Nauels, Y. Xia, V. Bex, P.M. Midgley (Eds.), Climate Change 2013: The Physical Science Basis. Contribution of Working Group I to the Fifth Assessment Report of the Intergovernmental Panel on Climate Change. Cambridge, United Kingdom and New York, NY, USA, Cambridge University Press, 27 pp.

Jones, P.D., Bradley, R.S. 1992. Climatic variations over the last 500 years. In: R.S. Bradley, P.D. Jones (Eds.), Climate since AD 1500. London and New York, Routledge, pp. 649-665.

Kędzia, S. 2015. The occurrence of glaciers in the Polish Tatra Mountains during the Little Ice Age. Zeitschrift für Geomorphologie NF 59, 229-241. http://doi.org/10.1127/zfg/2014/0150.

Kirkbride, M., Everest, J., Benn, D., Gheorghiu, D., Dawson, A. 2014. Late-Holocene and Younger Dryas glaciers in the northern Cairngorm Mountains, Scotland. The Holocene 24, 141-148. https://doi.org/10.1177/0959683613516171.

Klippel, L., Krusic, P.J., Brandes, R., Hartl-Meier, C., Trouet, V., Meko, M., Esper, J. 2017. Highelevation inter-site differences in Mount Smolikas tree-ring width data. Dendrochronologia 44, 164-173. https://doi.org/j.dendro.2017.05.006.

Kuhn, M. 1995. The mass balance of very small glaciers. Zeitschrift für Gletscherkunde und Glazialgeologie 31, 171-179.

Kumar, R. 2011. Glacieret. In: V.P. Singh, P. Singh, U.K. Haritashya (Eds.), Encyclopedia of Snow, Ice and Glaciers. Springer, p. 436.

Lamb, H.H. 1972. The cold Little Ice Age climate of about 1550 to 1800. Climate: past, present and future. Methuen, London.

Lliboutry, L. 1954. The origin of penitents. Journal of Glaciology 2, 331-338.

Luterbacher, J., Xoplaki, E., Dietrich, D., Jones, P.D., Davies, T.D., Portis, D., Gonzalez-Rouco, J.F., Storch, H von, Gyalistras, D., Casty, C., Wanner, H. 2001. Extending North Atlantic oscillation reconstructions back to 1500. Atmospheric Science Letters 2, 114-124. http://doi.org/10.1006/ asle.2002.0047.

Mann, M.E. 2003. Little Ice Age. In: M.C. MacCracken, J.S. Perry (Eds.), Volume 1, The Earth system: physical and chemical dimensions of global environmental change. Encyclopedia of Global Environmental Change, John Wiley \& Sons, pp. 504-509.

Matthes, F. 1939. Report of Committee on Glaciers. Transactions, American Geophysical Union 20, 518-535.

Matthews, J.A., Briffa, K.R. 2005. The 'Little Ice Age': re-evaluation of an evolving concept. Geografiska Annaler 87, 17-36. http://doi.org/10.1111/j.0435-3676.2005.00242.x.

Matthews, J.A., Owen, G. 2010. Schmidt hammer exposure-age dating: developing linear agecalibration curves using Holocene bedrock surfaces from the Jotunheimen-Jostedalsbreen regions of southern Norway. Boreas 39, 105-115. http://doi.org/10.1111/j.1502-3885.2009.00107.x. 
Messerli, B. 1967. Die eiszeitliche und die gegenwartige Vertgletscherung im Mittelemeeraum. Geographica Helvetica 22, 105-228.

Milivojević, M., Menković, L., Ćalić, J. 2008. Pleistocene glacial relief of the central part of Mt. Prokletije (Albanian Alps). Quaternary International 190, 112-122. https://doi.org/10.1016/J. quaint.2008.04.006.

Ministere de l'Agriculture et de la Mise en Valeur Agricole, 1994. Jbel Toubkal. Feuille NH-29-XXIII1a.

Morris, S.E., Olyphant, G.A. 1990. Alpine lithofacies variation: Working towards a physically-based model. Geomorphology 3, 73-90. https://doi.org/0169-555X(90)90033-M.

Nicod, J. 1968. Premières recherches de morphologie karstique dans le massif du Durmitor (Crna Gora: Montenegro). Meditérraneé 3, 187-216.

Ohmura, A., Kasser, P., Funk, M. 1992. Climate at the equilibrium line of glaciers. Journal of Glaciology 38, 397-411. https://doi.org/10.1017/S0022143000002276.

Oliva, M., Serrano, E., Gómez-Ortiz, A., González-Amuchastegui, M.J., Nieuwendam, A., Palacios, D., Pellitero-Ondicol,R., Pérez-Alberti, A., Ruiz-Fernández, J., Valcárcel, M., Vieira, G., Antoniades, D. 2016. Spatial and temporal variability of periglaciation of the Iberian Peninsula. Quaternary Science Reviews 137, 176-199. https://doi.org/10.1016/j.quascirev.2016.02.017.

Palade, B., Palacios Estremera, D., Gómez Ortiz, A. 2011. Los glaciares rocosos de Sierra Nevada y su significado paleoclimático. Una primera aproximación. Cuadernos de Investigación Geográfica 37, 95-118. http://doi.org/10.18172/cig.1258.

Peyron, M. 1980. Les chutes de neige dans l'Atlas marocain. Revue de Géographie Alpine 68, 237-254.

Pope, R.J., Hughes, P.D., Skourtsos, E. 2017. Glacial history of Mt Chelmos, Peloponnesus, Greece. In: P.D. Hughes, J.C. Woodward (Eds.), Quaternary glaciation in the Mediterranean Mountains. Geological Society of London Special Publications 433, 211-236.

Raub, W.B., Post, A., Brown, C.S., Meier, M.F. 1980. Perennial ice massess of the Sierra Nevada, California. World Glacier Inventory. Proceedings of the Riederalp Workshop, September 1978. IAHS-AISH Publication 126, 33-34.

Raub, W., Brown, C.S., Post, A. 2006. Inventory of glaciers in the Sierra Nevada, California. US. Geological Survey Open-File report 2006-1239, 232 pp.

Roth von Telegd, K. 1923. Das albanisch-montenegrinische Grenzgebiet bei Plav (Mit besonderer Berücksichtigung der Glazialspuren). In: E. Nowack (Ed.), Beiträge zur Geologie von Albanien. Stuttgart, Schweizerbart, Neues Jahrbuch für Mineralogie, Geologie und Paläontologie, vol. 1, pp. 422-494.

Sarıkaya, M.A., Tekeli, A.E. 2014. Satellite inventory of glaciers in Turkey. In: J.S. Kargel, G.J. Leonard, M.P. Bishop, A. Kääb, B.H. Raup (Eds.), Global Land Ice Measurements from Space. Springer Praxis, pp. 465-480.

Schimmelpfennig, I., Schaefer, J.M., Akçar, N., Koffman, T., Ivy-Ochs, S., Schwartz, R., Finkel, R.C., Zimmerman, S., Schlüchter, C. 2014. A chronology of Holocene and Little Ice Age glacier culminations of the Steingletscher, Central Alps, Switzerland, based on high-sensitivity beryllium-10 moraine dating. Earth and Planetary Science Letters 393, 220-230. https://doi. org/10.1016/j.epsl.2014.02.046.

Schulz, O., de Jong, C. 2004. Snowmelt and sublimation: field experiments and modelling in the High Atlas Mountains of Morocco. Hydrology and Earth System Sciences 8, 1076-1089. https://doi. org/10.5194/hess-8-1076-2004.

Serrano, E., González-Trueba, J.J., Sanjosé, J.J., Del Río, L.M. 2011. Ice patch origin, evolution and dynamics in a temperate high mountain environment: the Jou Negro, Picos de Europa (NW Spain). Geografiska Annaler A 93, 57-70. http://doi.org/10.1111/j.1468-0459.2011.00006.x. 
Shakesby, R.A., Matthews, J.A. 1993. Loch Lomond Stadial glacier at Fan Hir, Mynydd Du (Brecon Beacons), South Wales: critical evidence and palaeoclimatic implications. Geological Journal 28, 69-79.

Shakesby, R.A., Matthews, J.A., McCarroll, D. 1995. Pronival ('protalus') ramparts in the Romsdalsalpane, Souhtern Norway: Forms, terms, subnival processes, and alternative mechanisms of formation. Arctic and Alpine Research 27, 271-282. http://doi. org/10.2307/1551958.

Smith, G.W., Nance, R.D., Genes, A.N. 1997. Quaternary glacial history of Mount Olympus, Greece. Geological Society of America Bulletin 109, 809-824.

Smith, K. 2004. Trekking in the Atlas Mountains. Cicerone Press, 160 pp.

Styllas, M.N., Schimmelpfennig, I., Ghilardi, M., Benedetti, L. 2016. Geomorphic and palaeoclimatic evidence of Holocene glaciation on Mount Olympus, Greece. The Holocene 26, 709-721. https:// doi.org/10.1177/0959683615618259.

Thomson, J. 1889. The ascent of Tizi Likump. Travels in the Atlas and southern Morocco. A narrative of exploration. Chapter XXX, pp. 456-467.

Tomkins, M., Dortch, J., Hughes, P.D. 2016. Schmidt Hammer exposure dating (SHED): Establishment and implications for the retreat of the last British Ice Sheet. Quaternary Geochronology 33, 4660. https://doi.org/10.1016/j.quageo.2016.02.002.

US Army Map Service 1943. Tahanout. Sheet 19. 1:125,000. Compiled from Service Géographique du Maroc 1:100,000, 1937 to 1940.

Vieira, G., Mora, C., Faleh, A. 2017. Ground surface temperatures indicate the presence of permafrost in North Africa (Djebel Toubkal, High Atlas, Morocco). The Cryosphere 11, 1691-1705. https:// doi.org/10.5194/tc-11-1691-2017.

Wagnon, P., Ribstein, P., Francou, B., Pouyard, B. 1999. Annual cycle of energy balance of Zongo Glacier, Cordillera Real, Bolivia. Journal of Geophysical Research 104, 3907-3923. http://doi. org/10.1029/1998JD200011.

Wilkinson, R. 2011. Late Holocene environmental change in the Prokletije Mountains, Montenegro and Albania. $\mathrm{PhD}$ thesis, The University of Manchester. $414 \mathrm{pp}$.

World Meteorological Organisation. 1998. 1961-1990 global climate normals. Electronic resource. National Climatic Data Center, US: Asheville, NC. (CD-ROM)

Woodward, J.C., Hamlin, R.H.B., Macklin, M.G., Hughes, P.D., Lewin, J. 2008. Glacial activity and catchment dynamics in northwest Greece: Long-term river behaviour and the slackwater sediment record for the last glacial to interglacial transition. Geomorphology 101, 44-67. https:// doi.org/10.1016/j.geomorph.2008.05.018. 